\title{
CORPOS PARTIDOS: ADORNOS CERIMONIAIS, BENZIMENTOS RITUAIS E A ESTÉTICA DA PRODUÇÃO NO ALTO RIO NEGRO*
}

Thiago Lopes da Costa Oliveira

“Remédio" para Kowai

Nos últimos três meses do ano de 2012, analisei, ao lado do patriarca dos Baniwa-Hohodeni, Laureano Valência, centenas de artefatos recolhidos entre os mais diversos povos que compõem o mosaico étnico da região do alto rio Negro (ARN) - povos de origem Tukano, Arawak e Maku. ${ }^{1}$ Fazíamos isso a partir de fotografias que eu captara nos principais museus etnográficos do Brasil. ${ }^{2}$

O trabalho na reserva técnica do Museu Paraense Emílio Goeldi, realizado em agosto daquele mesmo ano, deixara-me especialmente entusiasmado. Dentre os objetos fotografados, eu encontrara alguns dos poucos adornos rituais recolhidos entre os Baniwa, em toda a longa história do colecionismo rionegrino. Eles haviam sido coletados por Koch-Grünberg, no remoto ano de 1904, na mesma região onde mais de 100 anos depois, eu realizava meu trabalho de campo (Cf. Koch-Grünberg 2005:195-97).

É conhecido na literatura etnográfica o fato de os índios do ARN partilharem um amplo conjunto de objetos, em um sistema de cultura material bastante uniforme, sobretudo quando se considera os chamados "índios do rio" - grupos arawak e tukano oriental. ${ }^{3}$ Os adornos são mencionados mais frequentemente em trabalhos escritos junto a clãs menos afetados pelas fortes pressões assimilacionistas que marcam a história da região desde os primeiros contatos com colonizadores, já no século XVII. Sabe-se, que os Baniwa utilizavam objetos semelhantes àqueles empregados por seus vizinhos tukano - como os Barasana, os Makuna e os Desana. Contudo, há poucas descrições de primeira mão feitas sobre estes artefatos a partir dos próprios Baniwa. 
Quando mostrei as primeiras fotografias para Laureano, pude perceber, pela atenção vívida que dedicava a cada objeto, que ele compartilhava do meu interesse pelos adornos. O velho, nascido por volta de 1910, afirmou que pelo menos desde a primeira metade do século $\mathrm{XX}$, não vira mais ornatos como aqueles em uso entre os Hohodeni. A caixa de enfeites originais de seu clã, segundo me disse, fora destruída em um episódio de descimento que remontava ao século XIX (Cf. Oliveira 2015, cap. 1). Os adornos utilizados pelos Hohodeni após se recomporem deste infortúnio, teriam sido levados "por um alemão" em um período que - segundo pude estimar - seria próximo à década de 1940.

Descrevemos, então, cada objeto presente nas fotografias. Inicialmente, o tema que constituía a minha porta de entrada no universo da cultura material do ARN eram as matérias-primas com que são elaborados os artefatos, a localização destes materiais no território rionegrino e as técnicas de produção empregadas em cada caso.

Figura 1: Pente duplo de uma haste, Tukano, Tiquié, Koch-Grünberg 1905

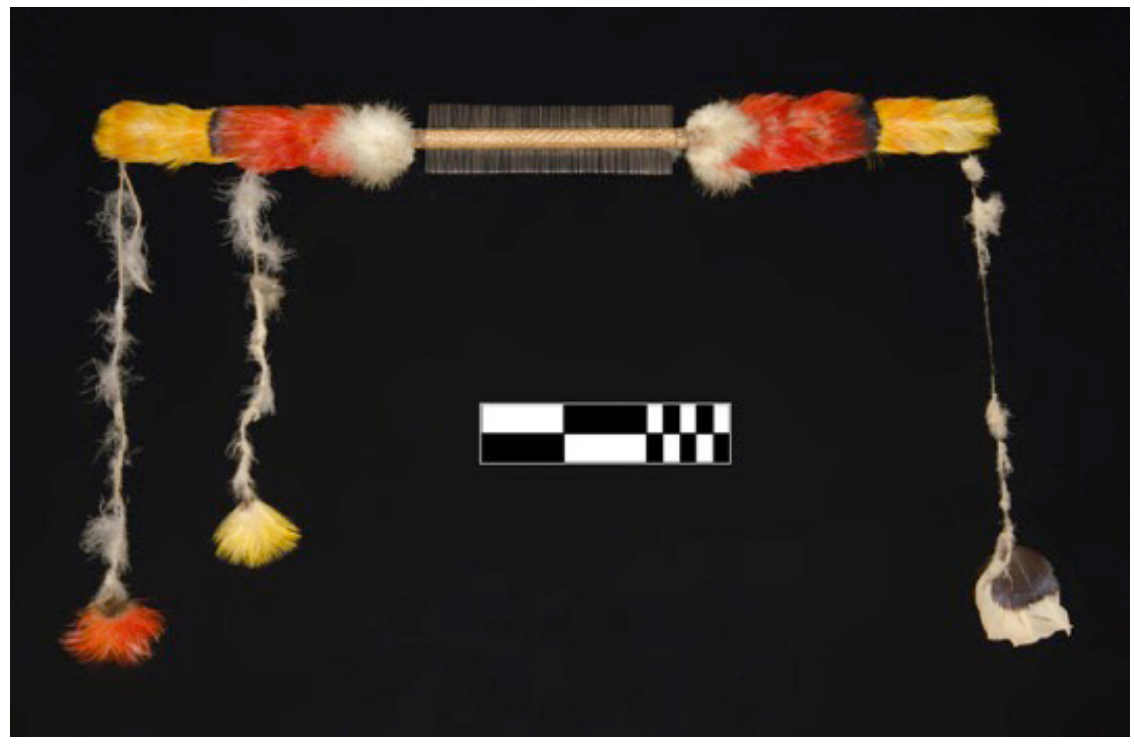

(C) Autor-MPEG (n. 250) 
Em dado momento de nosso trabalho, nos deparamos com um "pente duplo de uma haste" (Ribeiro 1988:177), o mesmo que se pode ver na Figura 01. Esse adorno plumário é feito a partir de uma haste de pau-brasil sobre a qual se dispõe, como cobertura, um finíssimo trançado de arumã. Pequenas lascas de paxiúba conformam os dentes do pente, saindo pelas tramas do trançado em duas direções paralelas. Ao final da endentação, estas lascas dão lugar a plumas e penas de tucano, presas por uma emplumação embrincada em círculo. Outras plumas do mesmo pássaro e também de uma espécie de gavião pendem das pontas do pente em fios de curauá, envolvidos, por sua vez, na plumagem branca do peito dos tucanos.

Embora tivesse origem no Uaupés - como era o caso do objeto analisado - Laureano confirmou que esse tipo de artefato era usado também entre os Baniwa. Eles chegavam até o alto Aiari por meio dos parceiros matrimoniais dos Hohodeni naquela região. Segurando a fotografia em suas mãos, Laureano disse que o nome do pente seria Kowai itaape, "remédio de Kowai". Tal forma de referência chamou imediatamente a minha atenção. Por meio dela, saíamos do universo mais estrito das técnicas e materiais para adentrar outras dimensões desse artefato.

Kowai - conhecido na língua geral pelo nome de Jurupari - é considerado o ser mais poderoso da cosmogonia rionegrina (ver Hugh-Jones 1979; Wright 1998). Laureano me explicou que o nome correto do pente seria mawida, e que o termo Kowai itaape derivava de uma história ocorrida, muito tempo atrás, com um casal que subia o rio Aiari em direção a Seringa-Rupitá - maloca dos Baniwa Hohodeni no interior de um dos formadores desse rio, o igarapé Uaranã - local próximo à aldeia de Ucuqui, onde nos encontrávamos naquele momento. Pelas nossas estimativas, esta história ocorrera por volta da primeira década do século passado, pois Laureano conhecera ambos quando era ainda criança (ver Oliveira 2015:413). A mulher chamava-se Kolhipeemi, um nome tradicional feminino do clã Hohodeni, e o homem se chamava Halene (macaco-prego branco), um apelido para um homem de origem do Uaupés. ${ }^{4}$

O caminho que seguiam, como contou Laureano, cruzava a cachoeira de Uapuí-Híipana - o sítio da emergência da humanidade, segundo os Baniwa. De uma abertura nas lajes dessa cachoeira, Naperikooli, o demiurgo baniwa, fez emergirem os ancestrais dos Hohodeni - e da humanidade como um todo - na origem dos tempos. Por esse motivo, esta era uma área sujeita a inúmeras interdições: no passado, era proibido o acesso de mulheres e não iniciados (nos rituais masculinos) ao sítio de emergência, bem como não se podia comer nas imediações desse sítio. Aqueles que viajavam pela região deviam arrastar sua canoa por um caminho paralelo à cachoeira de Híipana, e foi isso que o casal fez para seguir viagem. 
O acontecimento que nos interessa ocorreu mais a montante, quando eles encostaram para descansar e preparar uma refeição ligeira, em um ponto do rio situado acima de uma pequena corredeira - a cachoeira de Surubim - não muito distante de Híipana. Logo que começaram a comer, o céu se fechou e vieram de todas as direções raios e trovões. "Eram os Kowai!", disse Laureano. Vindos do alto do rio e de baixo, eles se aproximavam rapidamente. ${ }^{5}$ Isso ocorreu porque, por descuido, Kolhipeemi e Halene infringiram uma regra fundamental para se fazer uma refeição nas imediações de Híipana: eles não aqueceram apropriadamente os alimentos. Percebendo-se progressivamente encurralados e prevendo seu fim, a velha Kolhipeemi procurou o pente mawida no meio de sua bagagem. Encontrou-o quando estavam prestes a sucumbir, jogando-o ao fogo em que haviam preparado a sua refeição. Seu ato fez com que imediatamente os Kowai se dispersassem e os trovões passassem a soar cada vez mais distantes. Eles estavam a salvo.

\section{Objetos que agem}

Não são raras as histórias como esta no ARN. Histórias que descrevem adornos rituais como artefatos com agência no mundo. Os Desana consideram, por exemplo, que ser tocado pelos adornos rituais do dono da caça, Vái-mahsë, resulta em diversas doenças (Reichel-Dolmatoff 1971:176). Estes relatos, contudo, referem-se não só a episódios ocorridos no passado distante ou a encontros com seres não humanos, mas também a fatos recentes. Uma dessas histórias ocorreu no ano de 2008, durante o processo de repatriamento de alguns conjuntos de adornos expropriados dos índios da região, ao longo do século XX, pelos missionários salesianos, e depositados no Museu do Índio das irmãs Auxiliadoras, em Manaus. ${ }^{6}$ Martini (2012) descreve detalhadamente como a população de Iauaretê - grande povoado indígena situado no rio Uaupés, fronteira do Brasil com a Colômbia - esperava com apreensão o retorno das peças levadas há décadas pelos padres salesianos que instalaram uma missão no local por volta do começo do século XX. Havia no ar o temor de que aqueles artefatos pudessem agir causando doenças, mortes e enfeitiçando as pessoas, passando de "dóceis xerimbabos" a "parentes canibais" (:339-342).

Esses relatos permitem elaborar ao menos duas questões importantes: como entender que "simples objetos" sejam, para os indígenas da região, artefatos capazes de agir diretamente sobre o mundo? E uma vez ajam, como entender o seu poder de causar doenças, mortes, ou se contrapor, como na história do pente de Halene e Kolhipeemi, à mais poderosa força concebida pelos índios da região, o Jurupari? 
Procurarei responder a estas questões por meio da discussão de temas que se complementam progressivamente: na próxima seção abordo a origem, a circulação e alguns aspectos da produção desses artefatos. Em seguida, enfoco a morfologia e a diversidade de materiais presentes em sua elaboração. Passo, então, ao centro de minha análise, no qual discuto a origem mítica dos materiais empregados nos adornos e os procedimentos rituais necessários para objetificá-los. Por fim, discuto como os benzimentos - atos rituais implicados nessa objetificação - podem ser comparados aos objetos que eles permitem criar, detendo-me na estética de sua produção e no seu caráter de imagem complexa.

Esses passos analíticos serão dados segundo uma abordagem sistêmica. Considero a mitologia, a sociologia, a economia e o ritual dos diversos grupos da região - falantes de línguas arawak, maku e tukano oriental - como passíveis de uma análise transformacional. ${ }^{7}$ Empiricamente tal perspectiva metodológica se apoia na existência daquilo que Cabalzar (2000) chamou de "nexo regional", ou seja, no reconhecimento dos laços supralocais que unem grupos distintos por meio de relações políticas, rituais e de trabalho em uma rede na qual "trocas de informações, bens e visitas são mais intensas" (:63). O nexo regional dos Hohodeni de Ucuqui-cachoeira, por exemplo, inclui - para além de comunidades baniwa que vivem nas imediações de Ucuqui - comunidades de origem tukano situadas na bacia do Uaupés, e outras comunidades baniwa e koripako situadas nas cabeceiras do rio Içana - bem distante de Ucuqui - e no baixo curso desse rio, já próximo a São Gabriel da Cachoeira. Esta posição faz dos Hohodeni uma das pontes entre os universos arawak e tukano oriental da região.

Nestes nexos regionais, incluem-se ainda as chamadas "redes de trocas rituais" (Lolli 2010); redes que se dispõem em continuidade com os circuitos de trocas matrimoniais, diferenciando-se por incluir os chamados grupos de "baixa hierarquia", como aqueles reunidos sob a denominação Maku. Uma vez que essas trocas rituais ocorrem entre indivíduos e grupos hierarquicamente diferenciados, como Yuhupde-Tukano por exemplo, elas apontam para algo importante a ser considerado nesta análise: a homogeneidade da concepção da pessoa na região, a despeito da sua diversidade linguística e hierárquica.

Estes dois fatos etnográficos - o nexo regional e a rede de trocas rituais - tornam a escrita a partir de uma perspectiva supralocal não apenas uma escolha possível, mas um imperativo para o adequado tratamento do tema da agência dos artefatos e da estética da produção rionegrina. 


\section{Adornos corporais: herança, circulação e produção}

\section{Herança}

O sistema de sistema de cultura material do ARN reúne uma vasta soma de artefatos, que abrange da cerâmica à plumária, passando por trançados, cordões, tecidos, adornos de materiais diversos, instrumentos musicais de variados tipos, além de armas, utensílios de madeira e pedra, e variados objetos rituais, mágicos e lúdicos. Adornos cerimoniais destacam-se entre esses objetos, sendo transmitidos em linhas agnáticas de sucessão patrilinear junto a outros bens palpáveis - como instrumentos cerimoniais - e também bens que nós chamaríamos de intangíveis, como nomes, porções de território e conhecimento ritual (músicas, danças, cantos, benzimentos). Tal transmissão ancestral de conhecimento faz parte de uma tecnologia ágrafa da memória que interroga frontalmente a ideia de "amnésia genealógica amazônica" proposta em algumas sínteses para a macrorregião, aproximando-se de noções ocidentais como patrimônio, herança etc. ${ }^{8}$

Os ornamentos cerimoniais do ARN podem ser classificados em três categorias: os enfeites "originais"; aqueles feitos "pelos antigos"; e os objetos "novos", produzidos recentemente (Martini 2012; Ferreira 2014). Se os adornos originais são acheiropoietai - feitos pelos deuses - os da segunda categoria foram elaborados num passado remoto, segundo técnicas altamente especializadas. Por estes motivos - relação com os deuses e excelência técnica - estes adornos distinguem-se dos objetos encontrados na terceira categoria. Eles são também associados a um período de pouco contato entre índios e não índios.

Diversos grupos da região perderam ao longo de suas histórias - por conta da pressão assimilacionista, do colecionismo missionário e científico - os adornos ancestrais, tendo produzido, em alguns casos, objetos novos para substituí-los. ${ }^{9}$ Tal é o caso dos Baniwa, que hoje usam peças contemporâneas em rituais modernos - como formaturas escolares (ver Figura 2). Esses objetos, elaborados de forma esquemática, não apresentam, por exemplo, as sofisticadas técnicas de transformação de materiais presentes nos adornos das duas primeiras categorias mencionadas acima, conservando apenas os traços mais gerais que os ligam aos objetos ancestrais. Neste trabalho abordo mais diretamente os objetos das duas primeiras categorias. 
Figura 2: Alunos na formatura anual da Escola Indígena Paamali

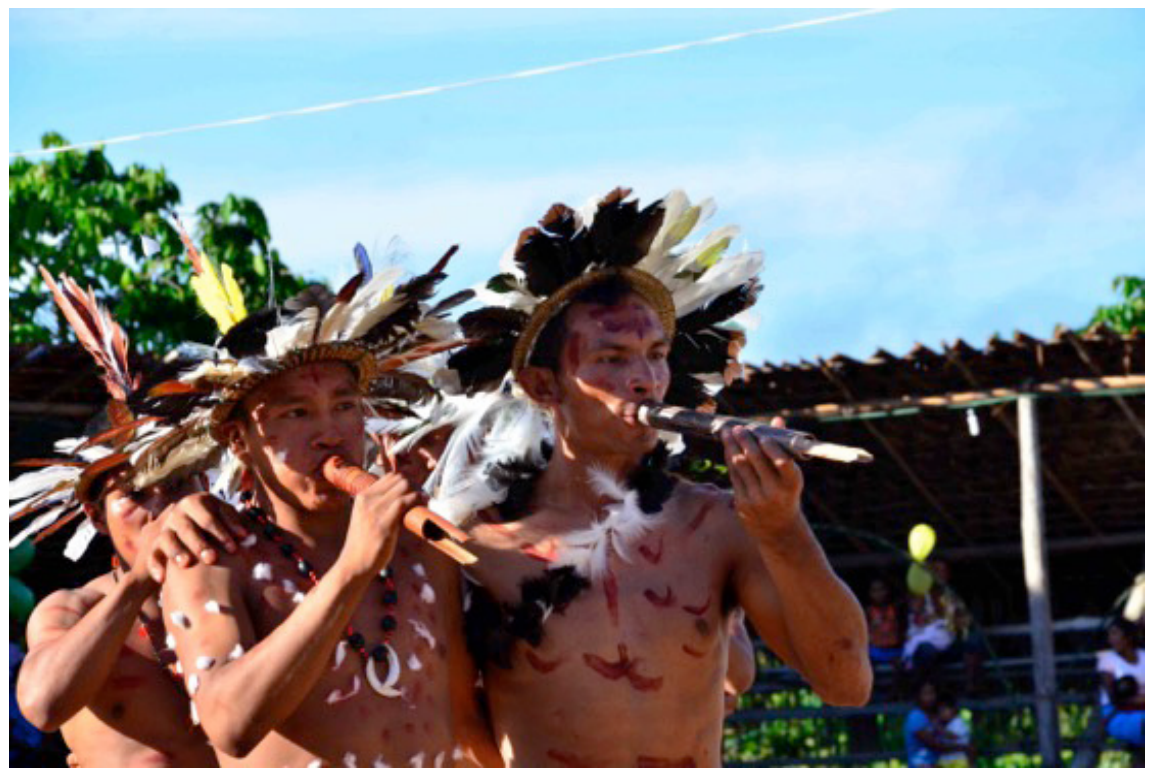

Autor, dezembro 2012

O sentido mais geral da transmissão dos objetos ancestrais, do passado ao presente, encontra-se codificado na tradição oral dos povos da região. Entre diversos grupos Tukano, como os Tariano, conta-se que os adornos foram recebidos por seus ancestrais proto-humanos no momento em que eles se diferenciavam da "gente-peixe". Tais objetos são, como argumenta Andrello (2006), uma segunda pele que distingue a humanidade dos seres que não acederam à condição humana plena ao final do tempo de criação. Nesse sentido, os adornos seriam "operadores de perspectiva" (:421): por meio deles, a humanidade se distanciaria da gente-peixe.

Na tradição baniwa, a origem destes artefatos é narrada de forma diferente. Os adornos são considerados um legado de Kaali, o "dono" dos alimentos cultivados. Em uma festa, ainda no tempo mítico, Kaali teria oferecido aos ancestrais de cada grupo - tukano e arawak incluídos - os adornos cerimoniais que eles transmitiriam de geração em geração a partir de então. Esta festa ocorreu após os humanos terem reavido os alimentos cultivados, descritos nas narrativas míticas como elementos diferenciadores de uma humanidade superior - aquela que cozinha os alimentos - e outra inferior - a que se alimentava de comida crua, coletada na floresta (ver e.g. Journet 1995:323). Nota-se, portanto, que por de trás da aparente diferença entre os mitos das tradições tukano e baniwa persiste uma mesma imagem 
dos ornamentos como uma "pele cultural" (Andrello 2006:380). No primeiro caso, esta pele distinguiria os humanos plenos dos proto-humanos; no segundo, os humanos que possuem determinados hábitos e conhecimentos culturalmente valorizados daqueles que não o possuem.

Há basicamente duas formas de se portarem os enfeites cerimoniais: uma mais simples e outra mais elaborada. A primeira é encontrada nos rituais do jurupari (ligados à ancestralidade), nos quais os ornamentos são eclipsados pela presença das flautas, dos trompetes e dos clarinetes cerimoniais. Nesse contexto, em determinados momentos, os participantes utilizam pequenas coroas de plumas de tucanos, sem aros de fibras de palmeira. Já a segunda forma de uso, na qual se emprega a totalidade dos adornos de um clã, é característica dos dabucuris, rituais que reúnem aliados por casamento, ou clãs-irmãos de um mesmo sib - (cf. Århem 1981:79ss.). Há indicações de que o nosso pente mawida seria utilizado por visitantes nos dabucuris (Koch-Grünberg 2005:306). Nessas ocasiões, partilham-se os adornos do clã que recebe hóspedes para uma festa, os convidados podendo levar também alguns objetos de uso pessoal. O uso dos conjuntos completos de adornos permite que, nos rituais, os humanos se assemelhem aos seus ancestrais proto-humanos. Voltarei a este ponto mais abaixo.

\section{Circulação}

Tradicionalmente estes enfeites eram guardados em uma caixa cuidadosamente depositada no interior das malocas, no alto, em um travessão situado acima do esteio do "cantor", uma das funções rituais características da região. Tal esteio, por sua vez, ergue-se sobre as sepulturas onde se enterram os homens de maior prestígio de cada clã. Esta posição - somada às narrativas de origem dos adornos - confere a estes artefatos uma forte relação com a ancestralidade.

Apesar desta ênfase na transmissão ancestral dos adornos, esses objetos também circulavam entre os clãs da região; o que era possível em virtude da relação entre herança vertical e aliança horizontal - ou seja, diante do equilíbrio entre a transmissão agnática de bens e a exogamia linguística e/ou clãnica no casamento. Um equilíbrio que, como sintetizou Andrello (2006), sugeriria que as "qualidades subjetivas também podem ser capturadas do exterior" (:269).

Assim, ao lado da herança, devemos considerar a fabricação, a troca e a venda como modos relevantes de se obterem estes objetos (Hugh-Jones 2014:160). As trocas poderiam ser pacíficas (ver Århem 1981:82) ou bélicas e o roubo de enfeites destacou-se, outrora, como um dos motores da guerra intertribal (Andrello 2006:339; Hugh-Jones 2014:159; Ferreira 2014:150). As 
trajetórias desses artefatos incorporavam-se a eles por meio de discursos e performances, constituindo um aspecto fundamental e suplementar de seu valor, somando-se ao prestígio derivado de suas origens ancestrais (Hugh-Jones 2014; Castro 2012).

Não é de se espantar, portanto, como afirma Goldman (1979), que alguns povos da região não tenham nunca elaborado tais artefatos (:153), e que outros tenham se tornado especialistas em sua fabricação - como os Desana (Nimuendajú 1950) - ou no fornecimento de matérias-primas para sua elaboração - como os Maku (C. Hugh-Jones 1979:52). Segundo os Hohodeni, alguns desses objetos também eram feitos pelos Baniwa - sobretudo os diademas trançados em mapanali (ver Figura 5), acompanhados de grinalda de penas de tucano; outros, contudo, eram adquiridos no Uaupés por altos valores. ${ }^{10}$

As formas horizontais de transmissão relacionam-se à unidade da concepção da pessoa, ponto que destaquei mais acima, e à uniformidade material desses objetos, como veremos mais abaixo. Estas trocas indicam que não era preciso produzir enfeites para se relacionar ritualmente com eles. Tendo-os herdado no tempo mítico, ou adquirido-os por meio de trocas bélicas ou comerciais, os índios da região, seja qual for a sua origem, encontravam-se fortemente envolvidos com adornos cerimoniais.

\section{Produção}

A confecção de adornos é uma atividade extremamente perigosa. Entre os Barasana, o período preferencial para se produzir estes artefatos ocorre após a iniciação masculina. Esta é uma atividade realizada exclusivamente pelos homens na região, cuja contraparte feminina é a produção de carajuru, um pigmento vermelho de propriedades rituais e medicinais. Durante a iniciação, os jovens de ambos os sexos estão ligados ao mundo sobrenatural e às forças criadoras do universo - o que favorece tal produção (Hugh-Jones 2014:162). Fora dos contextos rituais (fortemente protegidos pelos especialistas rituais xamânicos), a elaboração de adornos requer o recurso a um saber especializado, os chamados "benzimentos", especialidade dos benzedores ñapakaitta entre os Baniwa. ${ }^{11}$ Em associação com este conhecimento é preciso realizar, ainda, dietas restritivas de gordura animal e reclusões especiais (ver Ramos et al. 2012:88, 102 sobre os Tuyuka).

No que se segue, procurarei explicar justamente o fundamento destas restrições, descrevendo como os humanos se ocupam daquilo que é originalmente uma atividade dos deuses e dos seus ancestrais primários - a fabricação de adornos. Minha análise tomará um caminho ainda pouco trilhado na literatura da região, na medida em que enfocarei os relacionamentos 
entre humanos e os materiais empregados na produção de ornamentos. Sigo este caminho a partir da hipótese de que um olhar sobre a produção de tais objetos - e sobre a "estética da produção" (Overing 1989; Van Velthem 2003) da região - oferecerá uma nova chave para a compreensão de sua ação no mundo.

\section{Complexidade material dos adornos rituais rionegrinos}

Dentre os inúmeros artefatos produzidos no ARN, os adornos cerimoniais compreendem os objetos cuja composição é a mais complexa. Estes artefatos são os únicos em que se emprega componentes de origem animal, para além dos materiais vegetais presentes também em outros campos da cultura material.

Chama a atenção na análise dos enfeites rionegrinos que os materiais empregados na sua elaboração não expressem - ao contrário do que se observa entre os Bororo ou entre os Kayapó, por exemplo - diferenças entre os clãs ou linhagens que os possuem (cf. Dorta 1981; Turner 1980; Lea 2012). A lógica que orienta o uso e a posse de ornamentos é a mesma que estrutura as sociedades da região: de um lado, existe uma hierarquização "externa" entre aqueles que possuem ou não o direito de adornar-se, ou seja, entre pessoas de dentro e de fora do sistema (ver Hugh-Jones 2014:163) e, de outro, observa-se uma hierarquização "interna" entre os papéis-funções sociais ocupados por especialistas rituais (pajés/benzedores/cantores), chefes, guerreiros e servidores, característicos da organização social da região. Cantores e dançarinos vestem-se com a maior parte dos adornos coletivos, sendo que os primeiros possuem certos objetos exclusivos. Já os pajés e os benzedores utilizam objetos específicos de suas posições sociais (ver Reichel-Dolmatoff 1971:116, 136, 143 sobre os Desana; Århem 1981:79 sobre os Makuna). Jovens não iniciados, por sua vez, não podem usar ornamentos, assim como as mulheres de qualquer idade. ${ }^{12}$

Para entrever a diversidade de materiais empregados nesses artefatos apresento uma relação dos enfeites usados coletivamente por cantores e dançarinos na região - a maior parte deles acondicionada nas famosas caixas de adornos rituais, chamadas paato entre os Baniwa. Como veremos, esta descrição refere-se a nada menos do que 26 artefatos portados pelos dançarinos da região, entre adornos e objetos complementares. ${ }^{13}$ 
Figura 3: Caixa de adornos cerimoniais. Coleção Jaramillo Taylor.

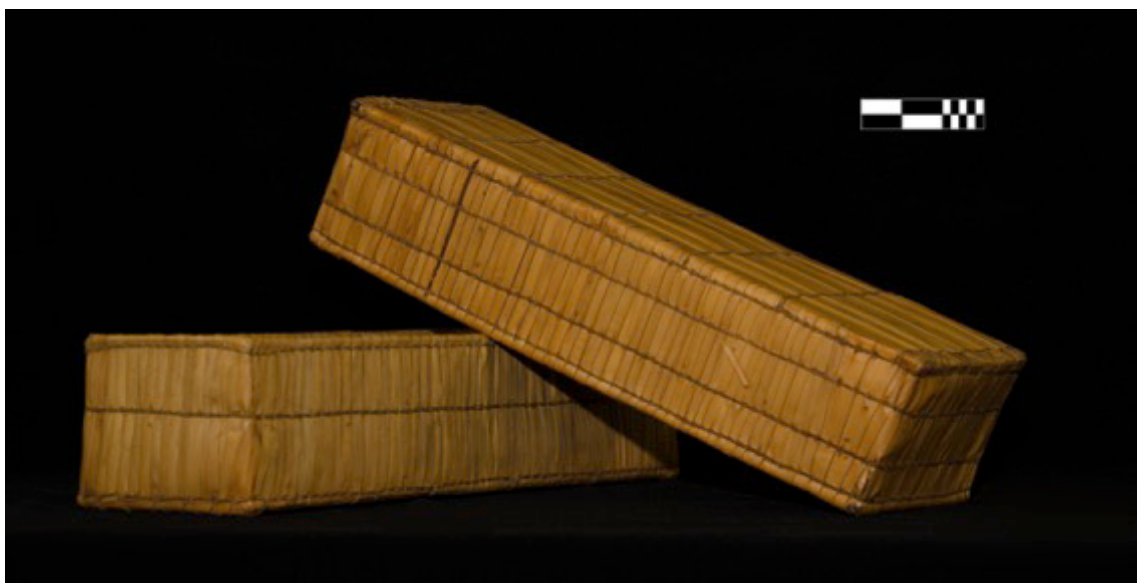

(C) Autor - MN (n. 21383)

Figura 4: Faixa emplumada, Tukano-Tiquié,

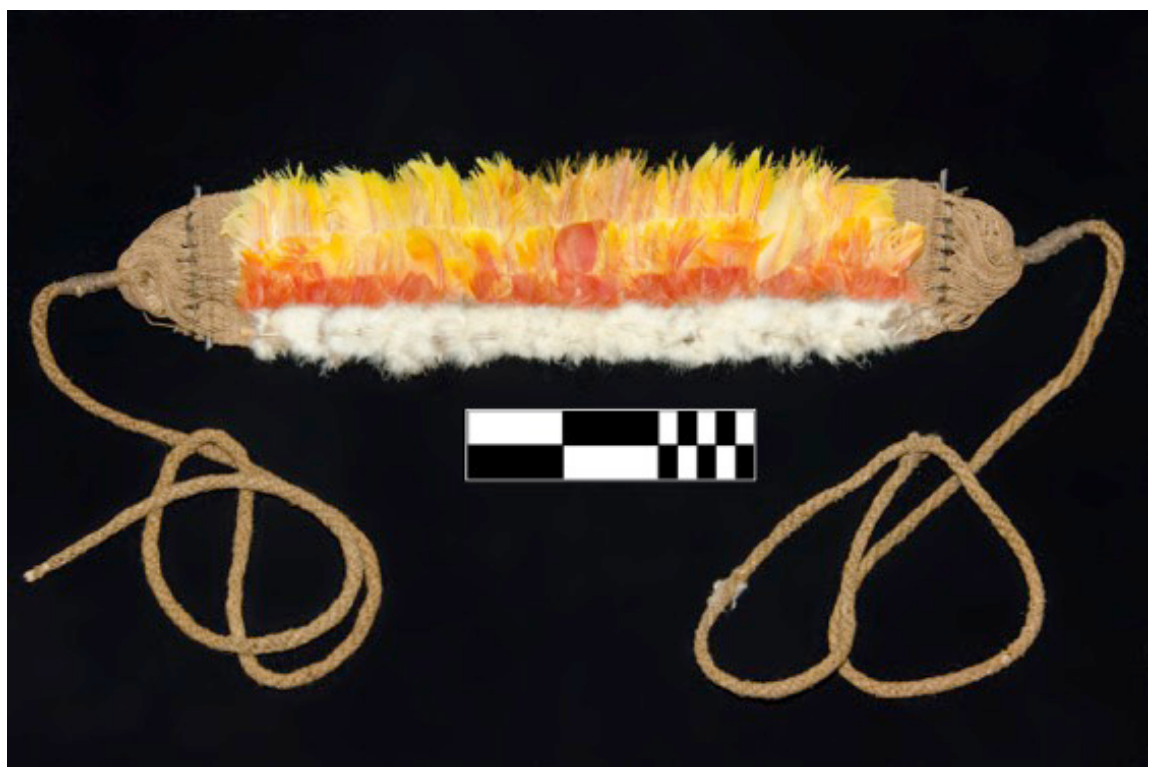

Koch-Grünberg 1905. (C) Autor - MPEG (n. 225) 
Figura 5: Coroa radial emplumada, Baniwa, Aiari, Cururu-Cuára,

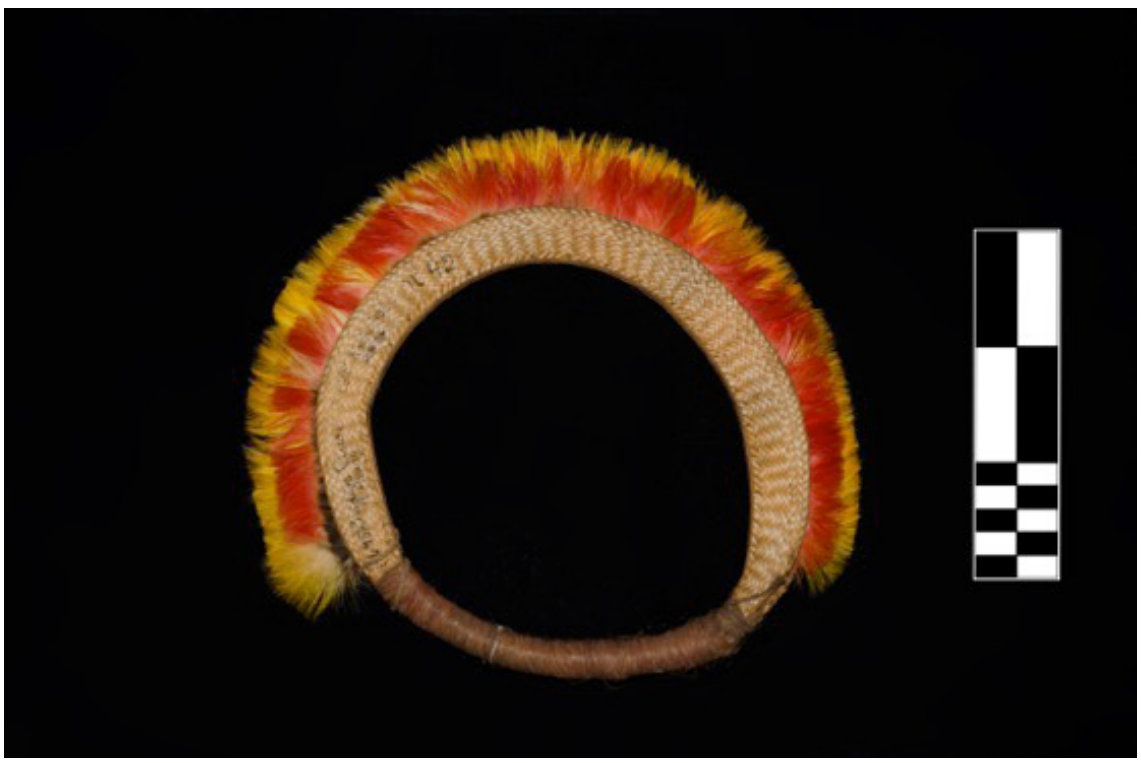

Koch-Grünberg 1905. (C) Autor - MPEG (n. 312)

Figura 6 : Placas occipitais, Tukano-Tiquié,
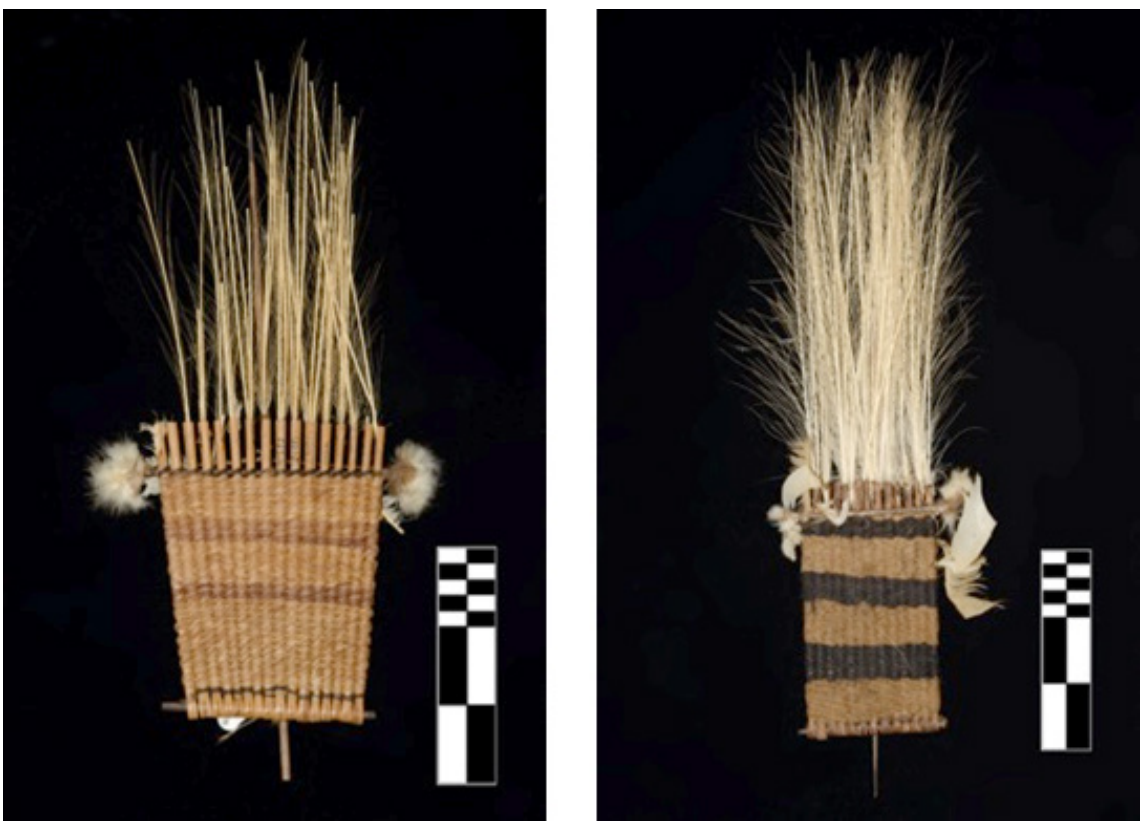

Koch-Grünberg 1905. (C) Autor - MPEG (n. 644 e 233) 
Figura 7: Pendente dorsal de élitros de besouro.

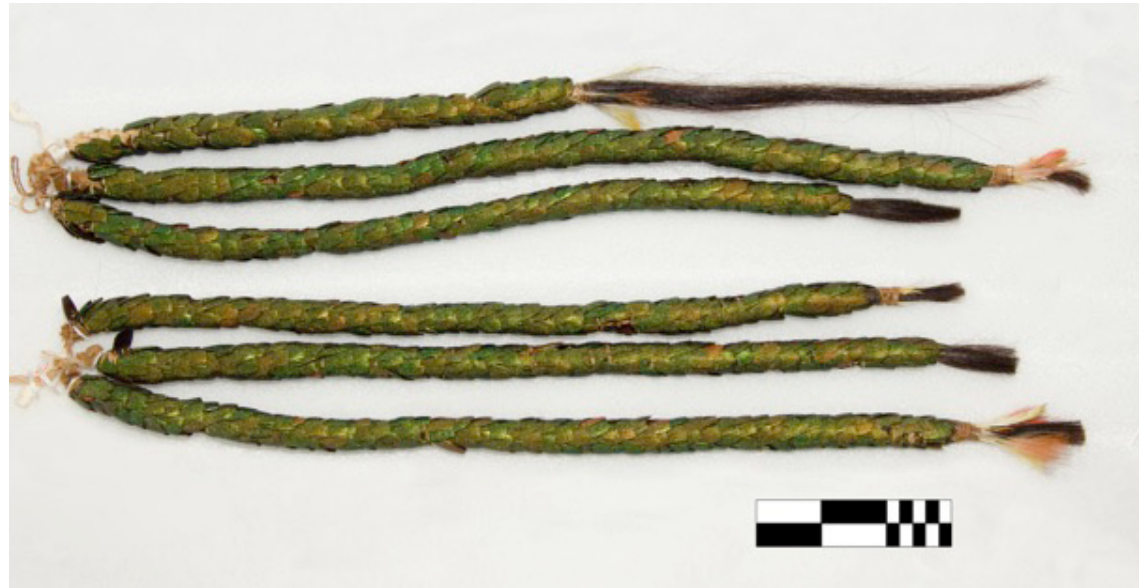

Coletor não identificado. (C) Autor - MN (n. 542)

Figura 8: Pendente dorsal de pelos de mamíferos, Tukano-Tiquié,

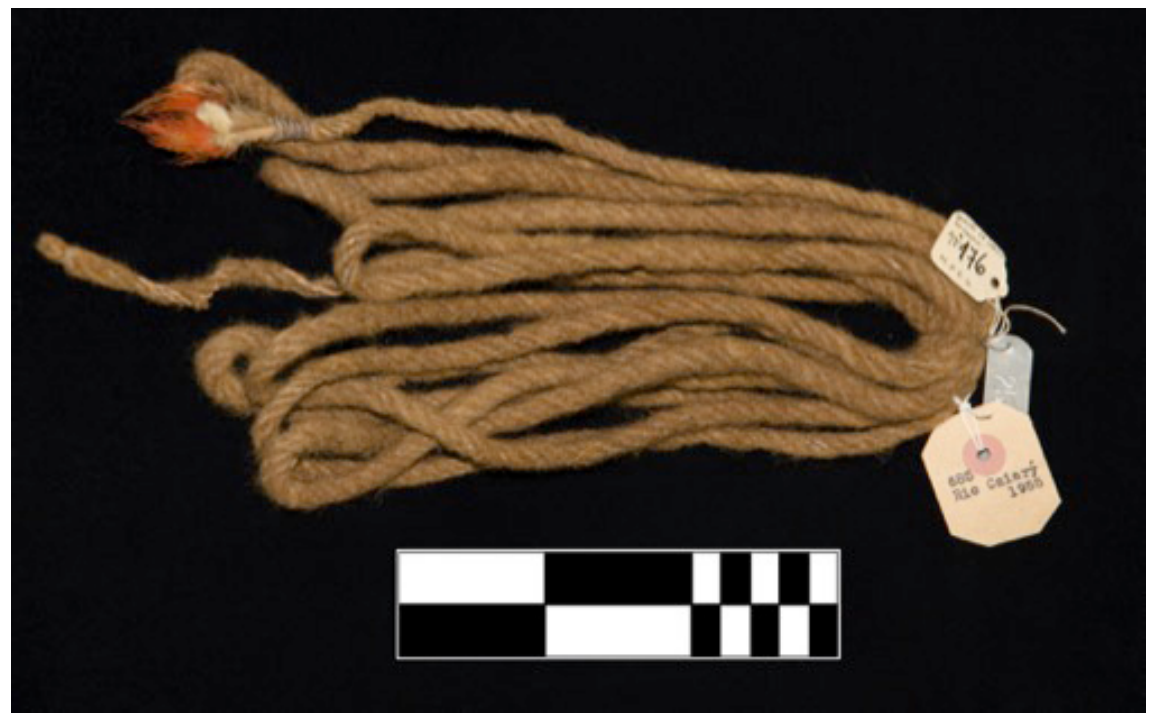

Koch-Grünberg 1905. (C) Autor - MPEG (n. 685) 
Figura 9: Colar de Quartzo Tukano, Boanerges de Souza Lopes, 1954.

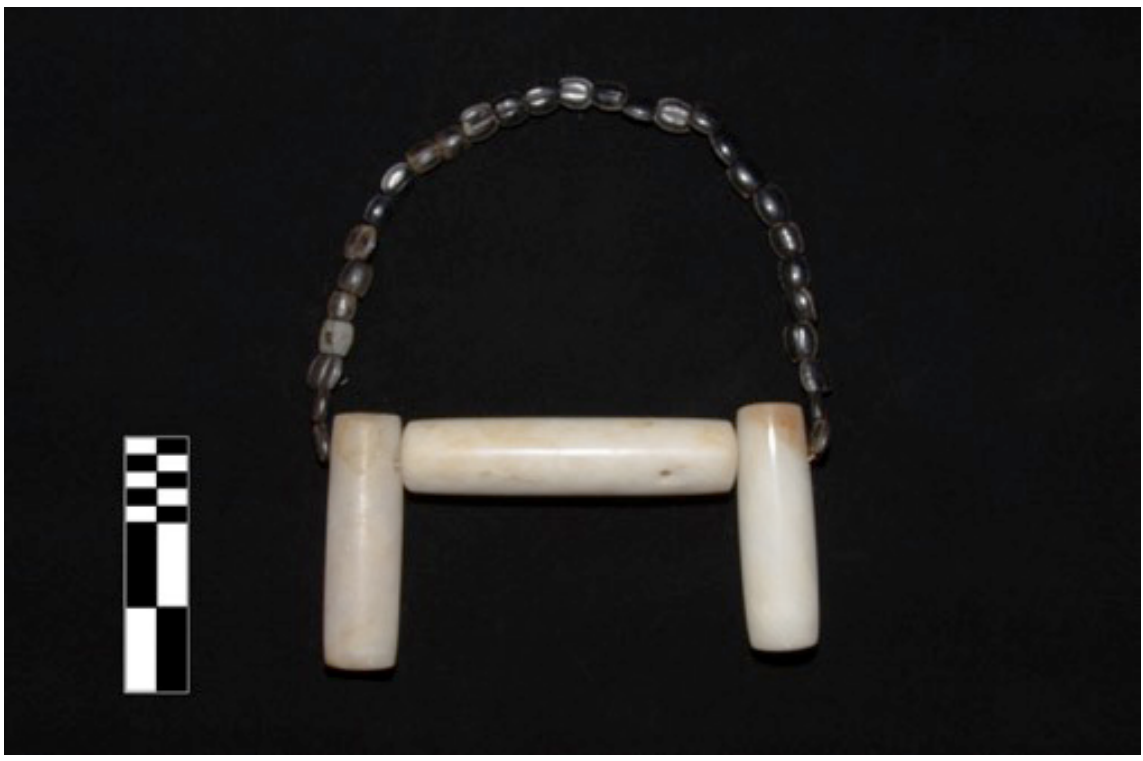

(C) Autor - MI (n. 6050)

Figura 10: Colar de dentes de Onça e Queixada. Rio Caiary-Uaupés,

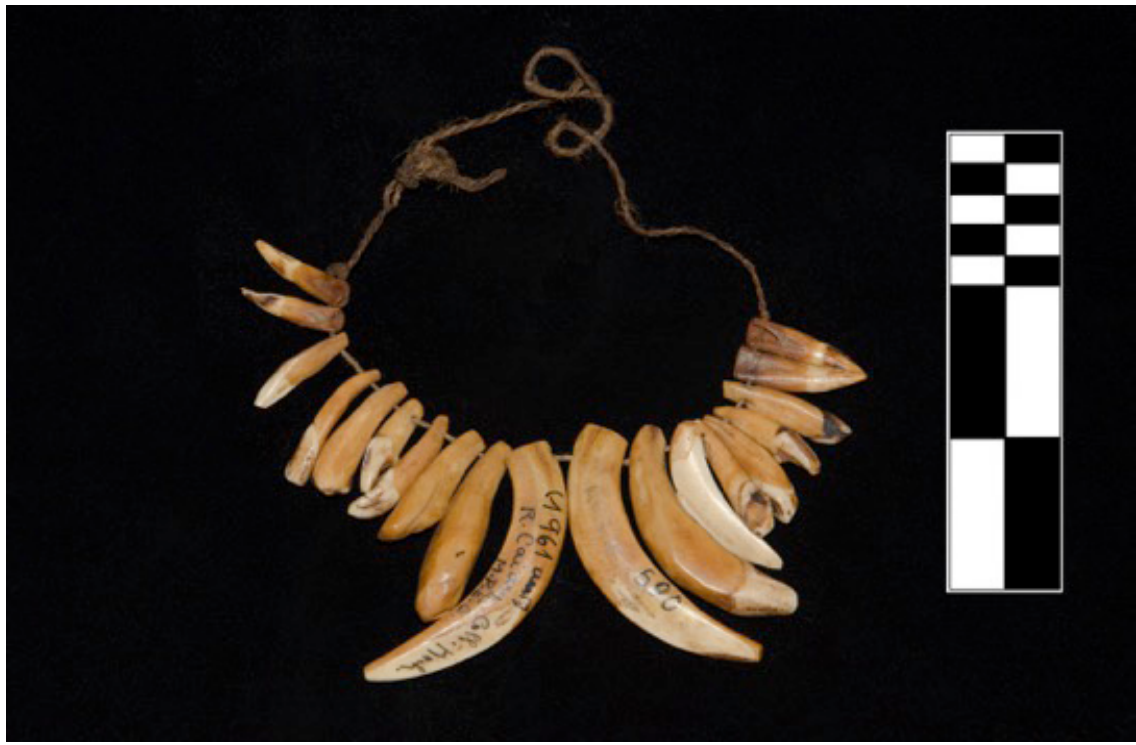

Koch-Grünberg 1905. C Autor - MPEG (n. 590) 
Adornos de cabeça:

1. faixa emplumada de penas amarelas e vermelhas de arara e brancas de urubu-rei;

2. coroa emplumada de penas amarelas e vermelhas de tucano sobre aro de folhas de palmeira;

3. coroa emplumada de penas amarelas e vermelhas de tucano (sem aro);

4. faixa de entrecasca colocada entre a faixa emplumada e a cabeça;

5. placa occipital vertical trançada com varetas vegetais e fios de pelo de mamíferos, da qual se erguem retrizes brancas da garça real;

6. pena retriz da cauda da arara vermelha e azul, ornada com plumas brancas de tucano;

7. osso tibial de mamífero (geralmente onças ou veados) preenchido com pelo de onça;

8. vareta envolvida em penugem branca de tucano, encimada com penas amarelas de japu ou verdes de papagaios - atravessa uma pedaço redondo de cuia ou de casco de tatu;

9. asa branca de garça;

10. feixe de cordas de pelos de mamíferos (macacos, preguiças e cabelos humanos);

11. brincos de lâminas de latão;

12. penas brancas - colocadas atrás das orelhas;

13. pendentes de élitros de besouro;

14. plumagem de garça branca espalhada sobre o cabelo;

Adornos de membros superiores:

15. bracelete de pelo de macaco, adornado com penas amarelas de japu, sementes de tucumã e/ou élitros de besouro;

16. chocalho de caracol e pendentes de élitros de besouro;

17. pulseira de sementes;

18. ervas aromáticas presas nos braceletes;

19. colar de dentes de mamíferos (onças, porcos, ariranhas etc.);

Adornos de tronco:

20. ervas aromáticas presas no cinto;

21. colar de prata martelada em triângulos;

22. cinto de dentes incisivos de onças e/ou porcos do mato;

23. colar de pingentes de quartzo montado sobre fio de curauá com sementes de seringueira;

24. avental de entrecasca com desenhos gráficos, pendendo da cintura até abaixo dos joelhos; 
Adornos dos membros inferiores:

25. chocalho de certo tipo de castanha;

26. faixa tecida de curauá adornada com desenhos gráficos e pendentes plumários.

Dentre as tendências observáveis quando se tomam esses objetos em conjunto, destaca-se, em primeiro lugar, em um jogo complementar, o privilégio dado à simetria e à transformação dos materiais empregados - encontrados raramente em sua forma natural. Em seguida, observa-se o privilégio dado a certas cores, notadamente "o preto, o branco, o vermelho e o amarelo" (Van Velthem 1975:13), mas também o verde e o bege/marrom. Outra tendência é a produção de objetos que ocupam volumes planos, próximos ao bidimensional, o que se deve ao recurso contínuo a diversos suportes feitos de materiais de origem vegetal, como aros e placas trançados, assim como faixas tecidas. ${ }^{14}$

Este é um ponto importante. Os materiais vegetais cumprem, aqui, uma função integradora. Eles permitem sustentar as penas em diademas, placas occipitais ou faixas de testa. São fiados e trançados de modos diferentes em cintos de dentes de onças e queixadas ou em chocalhos de sementes. Dão sustentação aos pendentes de pelos de mamíferos e permitem amarrar outros componentes animais, como conchas de caramujos, élitros de besouro e cascos de tatus aos ornamentos.

Figura 11: Detalhes

a. tecido e enfiada de frutos em cordel de um chocalho de tornozelo b. trançado da peça. Koch-Grünberg 1905
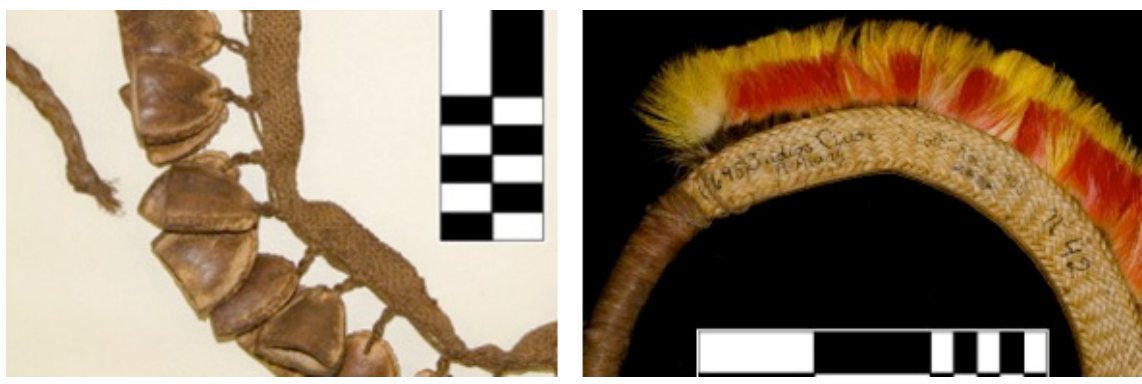

(C) Autor - MPEG (n. 798 e 312) 
São os materiais de origem animal, contudo, que se destacam no discurso nativo. Os Tuyuka, por exemplo, nomeiam o conjunto dos enfeites por um termo que pode ser traduzido por "pássaros-adornos" (Ramos et al. 2012), enquanto os Barasana denominam este mesmo conjunto de "xerimbabos-adornos" (Hugh-Jones 2014). ${ }^{15}$ Além disso, cada enfeite tem seu nome particular inspirado no animal cujas exúvias foram empregadas em sua elaboração.

Após analisar detalhadamente algumas dezenas de imagens de adornos, Laureano e eu chegamos ao total de 39 espécies animais, 12 vegetais e dois tipos de minerais empregados no fabrico destes artefatos. Entre as aves, encontramos além das já citadas garças, urubus-rei, araras, araras azuis e vermelhas; papagaios e tucanos (tucanaçus), também certos detalhes feitos de penas e plumas de patos do mato, gaviões de penacho, três tipos de mutum, galos domésticos, perus selvagens, pavõezinhos do Pará, galos da serra, anambés de peito roxo, japus e saís-azuis. ${ }^{16}$

Entre os mamíferos listamos: ariranhas, onças pardas, pintadas e negras, macacos barrigudo, guariba, prego, caiarára, zog-zog, queixadas e caititus, bem como esquilos, preguiças, tamanduás e tatus. ${ }^{17}$ Entre os peixes e répteis - usados apenas em enfeites pessoais - encontramos piranhas, crocodilos, jacarés comuns e surucucus. ${ }^{18} \mathrm{E}$ ainda alguns insetos - coleópteros - e moluscos, como um gastrópode não identificado.

Entre os vegetais está presente uma marantácea, o arumã, e quatro palmeiras: mawixapi (não-id.), a paxiúba, o tucum e o tucumã. Além disso, temos uma bromeliácea, o curauá, sementes de seringueira, de mooxe (não id.), e a entrecasca de duas árvores e um tipo de cuia também não identificados. ${ }^{19}$ Finalmente, encontramos o mineral quartzo branco e uma liga de metal, o latão, em adornos considerados, também, enfeites pessoais.

\section{Engendramento corporal}

\section{Cartografia relacional}

Ao longo de minha pesquisa, percebi que, quando olhavam para esses artefatos, ou para as suas fotografias, meus interlocutores eram capazes não só de identificar cada tipo de material usado, mas também de precisar quais eram os intermediários humanos ou não necessários para a sua aquisição. Cada um dos objetos ofereceria, portanto, uma imagem relacional da sua produção, imagem esta que é, ao mesmo tempo, cartográfica, posto que tais materiais e intermediários se distribuem desigualmente pela região (ver Oliveira 2015 caps. 4 e 5). No que se segue, pretendo demonstrar como 
uma determinada concepção da origem dos materiais empregados nesses artefatos determina os contingenciamentos rituais necessários para elaborá-los, concentrando-me em alguns aspectos desta cartografia relacional. Tomo minha etnografia com os Hohodeni como ponto de partida, mas retorno às comparações mais gerais em seguida.

Aves e outros animais são caçados na mata, longe das aldeias. Os vegetais empregados nos adornos provêm da floresta, das roças e dos igapós - onde se encontram, por exemplo, as resinas que prendem algumas das penas aos enfeites. Estas informações nos interessam porque estes espaços são objeto de reflexão especial da tradição oral baniwa. Eles são referidos a Kowai, Kaali, Omawali e Dzóoli, protagonistas nos mitos deste povo. Tais figuras são os "donos", liminali desses territórios ou domínios territoriais (ver Fausto 2008). São eles que engendraram, no passado mítico, as áreas em que se buscam os materiais usados na confecção dos adornos e de outros objetos. A tabela abaixo representa esquematicamente a relação entre donos e domínios, destacando a porção do mundo vivido baniwa atribuída a cada um dos personagens míticos mencionados.

Tabela 1: Domínios do mundo vivido Baniwa-Hohodeni, ARN

\begin{tabular}{|c|l|c|}
\hline Personagem & \multicolumn{1}{|c|}{ Seres } & Domínio \\
\hline Kowai & $\begin{array}{l}\text { animais terrestres, } \\
\text { arborícolas e celestes, } \\
\text { além de cipós e palmei- } \\
\text { ras diversas }\end{array}$ & mata, a floresta \\
\hline Kaali & $\begin{array}{l}\text { plantas cultivadas e que } \\
\text { nascem nas capoeiras }\end{array}$ & roças e as capoeiras \\
\hline Dzóoli & resinas, paricá e tabaco & $\begin{array}{l}\text { igapós e igarapés (tran- } \\
\text { sição entre água e terra, } \\
\text { entre rios e florestas) }\end{array}$ \\
\hline Omawali & $\begin{array}{l}\text { peixes e recursos } \\
\text { aquáticos (ou semi- } \\
\text { aquáticos) }\end{array}$ & mundo aquático \\
\hline
\end{tabular}

Donos e domínios

As relações de domínio-engendramento constituem uma das explicações para a necessidade dos atos rituais implicados na produção dos ornamentos e de outros objetos. Para entender o que isto significa, apresento, em seguida, as principais características atribuídas a estes personagens na tradição oral baniwa. 


\section{Kowai - Florestas e seres que nelas habitam}

O ciclo de episódios da história de Kowai narra o nascimento, a morte e as metamorfoses deste herói, bem como a transmissão de um legado amplo, composto de cantos, instrumentos cerimoniais, remédios, venenos, conhecimento ritual e xamânico, às futuras gerações. ${ }^{20}$ Esses episódios ocorrem no tempo dos Hekoapinai, "seres do amanhecer", personagens proto-humanos da mitologia baniwa que viviam em um mundo diminuto. Destaca-se, nessas histórias, a relação entre multiplicidade e singularidade característica de Kowai, seu legado sendo relacionado às partes de seu corpo (ver González-Ñañez 2007; Wright 2013:341, 2015; Oliveira 2015:191).

Após seu nascimento, Kowai é isolado no céu por seu pai, Naperikooli, e privado do convívio com sua mãe, Amaro, em virtude de sua monstruosidade: seu corpo era coberto de pelos e repleto de aberturas por onde saíam sons. Em sua ascensão, estes sons são cantados por toda parte, o que espalha pelo mudo os seres contidos no corpo Kowai, resultando na expansão e na diversificação do universo.

Tal é, para os Baniwa, a origem do que chamamos de "natureza", como me explicou certa vez Laureano. Mais tarde, Kowai será morto por Naperikooli, sendo jogado em uma fogueira. Das cinzas de seu corpo crescerá uma palmeira que, seccionada, dará origem aos instrumentos-Kowai, as "flautas sagradas" do Jurupari. Herdando a potência criativa primordial de Kowai na forma de instrumentos, os humanos passarão, eles mesmos, a cantar os nomes de todos os seres do mundo por meio desses aerofones, repetindo o ato primordial de criação a cada ritual de iniciação masculino.

\section{Kaali - Roças e capoeiras}

As narrativas baniwa ressaltam o papel de Kaali como mediador entre as fases proto-humana e humana da ocupação do mundo. O herói encarna duas figuras complementares: a "Grande Árvore", Kaali ka thadapa - que faria a ligação entre o céu e a terra nos tempos primordiais (Wright 1999:45) - e o avatar de Kaalittairi, um chefe de maloca, de aparência humana, vivendo junto à sua família.

Apesar da forma humana, Kaalittairi possui poderes sobre-humanos. Seu corpo insemina magicamente as roças, de modo que as plantas cultivadas e aquelas que surgem nas capoeiras (terrenos em que o cultivo agrícola foi interrompido) são um legado corporal desse herói. Tais plantas são fundamentais para a cultura material dos povos da região, sendo empregadas em diversos campos, da cestaria à fabricação de instrumentos musicais como flautas de pan, clarinetes, bastões de ritmo etc. 
Na mitologia baniwa e de outros grupos da região, o dono da alimentação encontra-se fortemente relacionado aos ornamentos corporais. Sempre que insemina as roças, Kaali está adornado, ou porta artefatos, como a lança-chocalho e o escudo trançado (Cornelio et al. 1999; Oliveira 2015:168). ${ }^{21}$ Estes objetos são considerados kaaliikolika, a "beleza", os "ornamentos" de Kaali. ${ }^{22}$ Em uma das versões desana, o herói da agricultura transforma-se efetivamente em ave, tendo o corpo recoberto de penas antes da fertilização das roças (Kumu \& Kenhíri 1995 [1980]), o que indica uma relação entre a transformação interna - o engendramento de alimentos e plantas úteis - e uma transformação externa - o uso de artefatos e o "crescimento" de penas como complemento deste corpo. Tais objetos e ornamentos são a condição para que o corpo múltiplo de Kaali - monstruoso como o de Kowai - produza singularidades extensivas, ou seja, objetifique seu poder em artefatos, vegetais e conhecimentos.

\section{Dzóoli - lgapós}

Dzóoli é um dos irmãos do demiurgo Naperikooli. Considerado o ancestral de todos os pajés maliri, relaciona-se aos igapós na medida em que neste bioma se encontra o paricá -alucinógeno utilizado pelos pajés em seus transes curativos - e diversas plantas resinosas das quais se fazem usos diversos, inclusive medicinais.

A história mais importante sobre Dzóoli refere-se à origem do tabaco. Os Baniwa narram que Naperikooli estava fora de casa quando seu irmão passou para lhe entregar o tabaco, conforme haviam combinado previamente. Na ausência do herói, Dzóoli, circulando a maloca em que vivia Naperikooli, inseminou o tabaco no terreno do irmão. Quando se virou para partir, ao descer para o porto, os sobrinhos de Naperikooli viram as plantas de tabaco saindo diretamente de suas costas: o tabaco era o próprio corpo de Dzóoli. Ao verem esta monstruosidade, os sobrinhos de Ñaperikooli ficaram maapikapha (prostrados, pasmados), tendo de ser mais tarde curados por seu tio.

\section{Omawali - O Sucuriju, dono do mundo aquático}

Omawali é o último personagem que nos interessa aqui. O Sucuriju aparece nas narrativas baniwa como um humano, vivendo em uma maloca, tendo mulher, filhos, fazendo festas e tomando caxiri. Os peixes, a gente de Omawali, nesses mitos, são descritos fazendo dabucuris, usando adornos e viajando para as malocas dos cunhados (ver Garnelo 2005). Omawali é humano em um mundo em que ser humano é ser peixe. Em alguns dos mitos, Naperikooli se casa com uma de suas filhas. Em outros, ele tem de resgatar um sobrinho que foi morto pelo Sucuriju. Ainda em outras narrativas, o próprio Naperikooli é engolido por Omawali, precisando ser resgatado do 
estômago do Sucuriju por animais auxiliares (cf. Cornelio et al. 1999). Este antagonismo faz de Omawali um dos principais opositores proto-humanos de Naperikooli.

Omawali é o "dono" do mundo aquático e dos seres que nele habitam. Alguns dos recursos aquáticos, como o barro - retirado de barrancos úmidos, na beira de rios e igarapés - são derivados do corpo de Omawali, são suas fezes. Outros, como o arumã - empregado largamente na cestaria e em alguns adornos - são identificados com o Sucuriju por serem associados a "olhos d'água", nascentes, locais onde são encontrados em estado selvagem.

\section{A estética da produção divina}

Gostaria de insistir no tema que nos trouxe até estas narrativas: a origem corporal de certos seres, artefatos e conhecimentos presentes no mundo atual. Estas narrativas apontam para a contemporaneidade dos mitos na vida social rionegrina. Elas indicam como eventos ocorridos nos tempos primordiais atualizam-se continuamente no presente.

Os Baniwa empregam o termo yanhenke, "conhecimento", para se referir ao legado demiúrgico apresentado nessas histórias. E, como vimos, trata-se de conhecimentos corporais objetificados em locais e em seres (animais e vegetais) diversos. Não estamos acostumados a pensar em uma incursão à floresta, por exemplo, como uma entrada em um domínio engendrado corporalmente por um ser poderoso. Assim como não pensamos em pássaros, jaguares, porcos-do-mato, em plantas cultivadas ou selvagens como partes de pessoas - neste caso, deuses/demiurgos. Contudo, de acordo com a tradição oral baniwa, é precisamente a partir dessas imagens que se deve interrogar a agência dos artefatos e dos materiais de que são feitos. Como partes destacadas, prolongamentos distribuídos de corpos poderosos, as matérias primas oferecem uma imagem indexical - e anicônica - dos corpos míticos. Como os mauri - pequenas pedras colocadas pelos Maori nas florestas para aumentar a sua fertilidade, seu hau (Gell 1998:107-8) - as matérias primas são a forma artefatual de uma potência vital.

A noção de exúvia, tal como empregada por Gell (1998) na análise da pessoa distribuída, é central aqui. Gell emprega o termo para tratar da distribuição dos corpos divinos em seus despojos, com o fim de resumir, em uma imagem, a ligação indexical entre um referente e aquilo que uma vez esteve ligado ao seu corpo - e que retém, por conta disso, sua potência (:114-16). No ARN, Hugh-Jones (2014) trata do assunto a partir dos Barasana, indicando como as exúvias de animais (cabelos, pelos, penas) são consideradas um índice de fertilidade (:165). ${ }^{23}$ 
Diante de tal origem corporal, as folhas de palmeiras, por exemplo, são tão ou mais importantes que as partes de animais presentes nos enfeites uma vez que estão fortemente associadas ao corpo incinerado e regenerado de Kowai. A relação entre as palmeiras e Kowai explicaria, aliás, por que se trançam os aros dos diademas emplumados a partir de folhas da palmeira mapanali e não da epiderme das cânulas de arumã, material tradicionalmente empregado nos trançados da região. Esta escolha relaciona os adornos a Kowai-Jurupari evitando, ao mesmo tempo, um material ligado ao dono do mundo aquático e opositor dos humanos, Omawali. Assim, em uma primeira aproximação da origem corporal das matérias-primas, vemos que é menos significativa a presença de um determinado material singular em um enfeite, do que a reunião de um conjunto de materiais diversos, uma vez que tais materiais apontam para a multiplicidade de seres contidos nos corpos poderosos dos demiurgos. ${ }^{24}$

A estética da produção aqui discutida por meio da tradição oral baniwa encontra eco em motivos míticos de outros povos da região. ${ }^{25}$ Uma narrativa tukano informa que os adornos originais de determinado clã foram vomitados pelos deuses nos tempos míticos (Kumu \& Kenhíri 1980 apud Hugh-Jones 2014:158). Já uma narrativa makuna explica que a fabricação dos adornos originais deste povo foi realizada pelos proto-humanos ao longo da viagem da "cobra canoa". Dos restos dos materiais empregados na elaboração dos artefatos primordiais tiveram origem os animais com os quais se fazem adornos no tempo atual (Århem 1988:58). Estamos, portanto, sempre no campo semântico dos processos de destotalização-retotalização e engendramento corporal. Assim, se os adornos são o "aspecto visível do Jurupari" (Hugh-Jones 2014:157ss), ou fazem os humanos assemelharem-se aos demiurgos, como afirmou Århem (1981:80-1), eles o são e o fazem ao figurar o estado transformativo (ver Fausto 2011) característico do tempo da criação.

Notemos, por fim, que as coisas derivadas de corpos divinos produzem, elas mesmas, exúvias - folhas, sementes, penas, pelos, dentes, cascos etc. Ao mesmo tempo em que são exúvias de animais e vegetais singulares, tais prolongamentos vitais são também as suas "armas" - para retomar uma expressão de Buchillet (1992:221), dada a partir dos Desana e de Hugh-Jones (1996b:140), feita a partir dos Barasana. No sentido heráldico empregado pelos dois autores, o termo "arma" evoca capacidades distintivas e inalienáveis dos seres. No contexto de sua transformação em produtos, como no caso da produção de alimentos, tais armas "devem ser queimadas para retornarem às suas malocas espirituais" (Hugh-Jones 2014:164). O que está em jogo aqui é a conversão do "corpo zoomórfico" - este "edifício de 'múltiplas almas'" (Fausto 2007:512) - em "identidades humanas" (Hugh- 
-Jones 2014:164), seja para alimentar-se de sua carne, seja para produzir enfeites cerimoniais. Tal conversão é feita por meio dos benzimentos; o que vêm a ser precisamente o tema das próximas seções.

\section{Os benzimentos}

Para os Baniwa, os benzimentos são manipulações dos nomes cantados por Kowai-Jurupari ao subir ao céu, expandindo o mundo e originando todos os seres viventes. A sua transmissão, contudo, é considerada um legado de Ñaperikooli, o demiurgo que aprendeu os cantos com Kowai para transmiti-los à humanidade. Enquanto atos produtivos, os benzimentos conectam os modos de produção do presente e do tempo da criação do mundo.

Benzedores são também chamados de "sopradores" na região. Segundo Hill (1993), o próprio termo ñapakaitta, pelo qual são designados, referir-se-ia ao ato de "soprar" (:126). Em português, emprega-se o termo "benzimento" para designar as fórmulas usadas para fazer o bem, e "sopro", para as fórmulas - conhecidas pelos mesmos especialistas - usadas para fazer o mal. Em baniwa, o termo ñapakatti designa as primeiras e o termo hiwiattii, as demais. ${ }^{26}$ Benzimentos são soprados em substâncias - plantas, resinas e líquidos - que transmitem seu conteúdo a um destinatário (ver Cayon 2010:307 sobre os Makuna). Podem também ser soprados diretamente sobre corpos, mas isto é considerado menos eficaz, pois as substâncias que recebem o sopro transmitem algo de si no processo de tradução que operam (Buchillet 1992:220). Os benzimentos estão entre os aspectos menos comunicáveis das tradições locais, tanto pela dificuldade de compreender suas fórmulas - feitas em linguagem não ordinária - quanto pelo fato de serem um conhecimento infraclânico, passado em certas linhagens em relações pai-filho e/ou avô-neto.

Não se conhece na literatura, até onde eu saiba, a forma exata que tomam as fórmulas utilizadas para elaborar os adornos rituais, e mesmo outros artefatos - como cacuris, zarabatanas - que requerem benzimentos para sua elaboração (ver Cabalzar 2005:309-310; Corredor 2011:43, 55, ambos sobre os Desana). De modo geral, procede-se, assim como nos benzimentos de nominação (Ferreira 2012:152), por meio da associação entre seres e lugares, percorrendo verbalmente as chamadas "casas de criação" (ver Cayon 2008, 2010 sobre os Makuna). O mesmo procedimento de identificação entre aquilo que vem de fora e o grupo que está acolhendo esta potência é assinalado por Ramos et al. (2012) no que se refere ao manejo dos xerimbabos cativados para fornecer penas e plumas aos produtores de adornos (:94). Estes animais também receberiam nomes do grupo que os cativa. 
Tal saber especializado está ligado não somente à produção, mas também ao uso dos ornamentos. A capacidade de portar e de manusear adornos é adquirida na "montagem" da alma da criança - por meio de um benzimento de nominação específico (F. Cabalzar 2010:120-135 sobre os Tuyuka). A manutenção dessa capacidade se dá ao longo da vida de uma pessoa por meio de jejuns, benzimentos de proteção e práticas rituais corretas (Martini 2012:341-2).

\section{Nomes de benzimento}

Durante esta pesquisa, após analisarmos as fotografias mencionadas anteriormente e levantarmos o conjunto de materiais empregados na produção de objetos no ARN, Laureano e eu passamos a identificar o nome de benzimento de cada material. Laureano é um reputado especialista, sendo requisitado diariamente para realizar benzimentos para outras pessoas. Segundo o velho Hohodeni, os nomes empregados pelos benzedores são sempre os mesmos, modificando-se apenas as formas e os contextos de sua manipulação. ${ }^{27}$ Este é um dado importante. Por meio dele compreendemos que, mesmo sem conhecer a exata estrutura de tais fórmulas, é possível, através da análise de suas unidades constituintes - os nomes de benzimentos (ñapakatti lipitana, em baniwa) - avançar na compreensão das relações entre produtores e materiais empregados nos enfeites. No que se segue, vou analisar em detalhes a formação desses nomes, dando ênfase para o modo como eles apresentam imagens complexas das "coisas" nomeadas. ${ }^{28}$

A menor unidade de um nome de benzimento na tradição baniwa é formada por duas partes: de um lado, encontramos uma descrição sensorial do ser nomeado e, de outro, uma descrição das relações de domínio em que se encontra este ser. Enquanto o primeiro aspecto do nome aponta para uma característica sensível (uma relação indicial), o segundo aponta para uma relação de pertencimento e para uma biografia daquela espécie (uma relação de englobamento), que conecta este ser a outro - geralmente a um dono-liminali, ou a um habitat ligado a este dono.

Para ressaltar esses dois procedimentos de composição, proponho chamar estes termos de nomes-complexos. ${ }^{29}$ A forma mais comum de se compor um nome complexo é unir um termo referente a uma característica sensível daquilo que se nomeia - geralmente uma metonímia derivada da percepção tátil, olfativa, visual ou auditiva desta "coisa" - a um classificador que a situa em um determinado ambiente. Nestes nomes, "a diversidade de espécies naturais no ARN é usada como um tableau poético de cores, sons, texturas e outras imagens" (Hill 1993:112). Os classificadores mais gerais são ooleñenai, éenoonai e keepinai. Eles se referem, respectivamente, a seres aquáticos, terrestres e celestes (ver Hill 1993:97-99), como resume a tabela abaixo. 
Tabela 2: Classificadores, ambientes e termos em baniwa

\begin{tabular}{|c|c|c|}
\hline Ambiente & Classificador (benzimentos) & Termo (ling. cotidiana) \\
\hline Celeste & Keepinai & Itsili iarakapewa \\
\hline Arborícola & Éenoonai & Itsili iwatshakape \\
\hline Terrestre & Ooleñenai & Itsili hipairiko \\
\hline Aquático & Koophenai \\
\hline
\end{tabular}

O recurso aos classificadores permite aos benzedores, nos benzimentos dos recém-nascidos, por exemplo, agrupar os nomes dos seres em conjuntos mais amplos - o que resulta na ordenação dos cantos de Kowai em um registro mais humano, posto que menos caótico e monstruoso. Esta estruturação em andares cósmicos corresponde, lembremos, ao modo como os adornos se dispõem nos corpos dos dançarinos. Se o corpo adornado é "um modelo do universo" (Hugh-Jones 2014:164), ele o é na medida em que oferece um mapa visual de processos mentais e pragmáticos mais amplos. ${ }^{30}$

\section{Nomes de benzimentos de animais}

No que se segue apresentarei quatro exemplos de nomes complexos dos materiais utilizados na composição de adornos, analisando a tradução livre oferecida verso a verso. Começo com o nome das garças, maali, de cujas penas, aigrettes e mesmo asas inteiras se fazem adornos plumários de cabeça.

Exemplo 1: Garça (Maali)

\section{Nhãlekaapa Kepinai}

A brancura dos animais celestes

\section{Liwanahe Eeno}

[que se encontra] Do outro lado do céu

Limalitsiali Itaada Dzáawi Naperikooli

No campo de Onça Ñaperikooli

O primeiro nome deste conjunto, Nhãlekaapa Kepinai, faz referência à brancura das penas e das plumas das garças. A palavra nhãlekaapa (nhãle = brancura; kaapa = ver/aparecer) é relacionada, ainda, à categoria dos "animais celestes", kepinai. O segundo nome situa essa imagem inicial em uma determinada região cósmica, "do outro lado do céu". Trata-se de uma alusão ao local para onde se dirigiu o herói cultural Naperikooli após o fim da criação. Este local é evocado no terceiro verso, que cita nominalmente um dos avatares do herói, Dzaawi Naperikooli, e os campos em que vive do outro lado do mundo (ver Journet 1995:111). Os nomes Dzaawi Ñaperikooli vinculam-se em geral a animais assistentes de Naperikooli, e seriam 
especialmente poderosos (Hill 1993:121). Destaca-se, assim, nesse primeiro exemplo, o modo como os nomes oferecem uma descrição sensorial e uma situação cosmográfica dos seres nomeados. O mesmo ocorrerá, de forma distinta, no próximo exemplo. Vejamos.

Exemplo 2: Queixada (aapi)

Os porcos do mato, queixadas, de cujos dentes se fazem os pendentes dos cintos usados pelos dançarinos, são chamados de apitsi na linguagem cotidiana. Nos benzimentos, eles são nomeados pelos seguintes versos:

Ropitanina pida rhoa maliweko itto

Xerimbabo da filha de Maliweko

Nadidikada éenonai

Os animais terrestres, "di di"

Naphaphakada éenonai

Os animais terrestres, "phá phá"

O verso inicial apresenta um componente biográfico. O nome ropirana pida rhoa Maliweko itto poderia ser traduzido como "o xerimbabo da filha de Maliweko". O termo "-pira", em baniwa, refere-se a "animal cativo" ou "de estimação", um xerimbabo. Itto é "filha", e designa a filha de Maliweko, o "dono" dos porcos do mato. Essa dupla referência aos "donos" destes animais - Maliweko e sua filha - traz consigo uma descrição cartográfica, na forma de uma menção indireta à ilha onde vive Maliweko, local considerado a "casa" de surgimento dos porcos do mato. Trata-se de uma ilha próxima à ilha das Flores, no ARN, situada acima da sede do município de São Gabriel da Cachoeira.

A esta referência cosmo-cartográfica soma-se uma segunda referência espacial concernente ao ambiente em que os queixadas se encontram com os humanos, presente no segundo e terceiro versos, através do emprego do classificador éenonai - animal terrestre. Tal classificador é combinado com duas imagens sonoras, evocadas pelos benzedores como o traço saliente e distintivo destes animais: a batida da mandíbula que, como sabemos, originou seu nome amazônico. Elas estão presentes no segundo e no terceiro verso, por meio de signos icônicos - "di di", "phá phá" - atribuídos a estes animais. 


\section{Nomes de benzimentos de vegetais}

Passemos a dois exemplos de vegetais utilizados na elaboração dos adornos. Comecemos pela palmeira mapanali, cujas folhas são tecidas, como já vimos, para elaborar os aros dos diademas de penas e as caixas que guardam os adornos. Em seguida, veremos o caso das sementes empregadas nos chocalhos de fieira que se amarram aos tornozelos dos dançarinos, chamadas wadzaapa.

Exemplo 3: mapanali

As espécies de palmeiras chamadas na linguagem cotidiana de mapanali [n.id.], mawixaapi [n.id.] e poonama [patauá] recebem um só nome-complexo, formado por três versos somados e apresentados em sequência:

\section{Limottokanatse éeno}

Que rasga/abre em direção céu

Littoropitsa éeno

O eixo do céu

Éeno kaphewida pokooali

As folhas pendendo do céu

Limottokanatse refere-se à imagem de abertura/saída (li-motto-ka $=3^{\mathrm{a}}$ pessoa sing.- sair (v)-terminativo) em direção ao céu, éeno. Littoroopi (-toro = enrolado, estriado) diz respeito à parte enrugada entre os "gomos" ou "nós" do espique (tronco) de palmeiras e cânulas. Em uma tradução mais sofisticada, segundo o hohodeni Afonso Fontes, esta parte seria chamada de "eixo do céu". Kaphe- é folha e -wida é cabeça; pokooali significa "recobrir tudo". Este último nome remete à imagem das folhas das palmeiras que se erguem do tronco antes de se inclinarem em direção ao chão. O que faz com que este nome-complexo comporte simultaneamente uma tripla imagem da palmeira: erguendo-se para o alto, com o espíque marcado por gomos e as folhas pendendo de sua copa. Esta é também uma imagem da dimensão vertical do mundo, uma vez que éeno pode ser traduzido por "céu", mas igualmente por "universo". Não há uma referência direta aqui a um "dono". Contudo, como vimos acima, as palmeiras são um avatar de Kowai-Jurupari, cuja transformação em palmeira precedeu seu ressurgimento na forma de instrumentos cerimoniais. 


\section{Exemplo 4: wadzaapa}

O nome das sementes empregadas nos chocalhos de pé é wadzaapa. Tal nome constitui o nosso último e mais simples dos exemplos. Nos benzimentos diz-se apenas:

\section{Littimakana Kaali}

A alegria de Kaali

Esse nome comporta apenas uma menção ao herói cultural que legou aos Baniwa o conhecimento cerimonial do dabucuri - sua "alegria". Nesses rituais, como vimos, dois grupos unidos por aliança matrimonial ou por agnação performam instrumentos, danças e cantos. Wadzaapa é a alegria de Kaali - um objeto referido a um dono - assim como o caxiri (bebida fermentada feita a partir da mandioca amarga) e os instrumentos e cantos dos dabucuris o são.

\section{Manipulando imagens complexas}

Por estes exemplos notamos que a tradição dos cantos de Kowai alimenta-se de um duplo movimento: de um lado, os nomes complexos nos levam para além da linguagem. Dizer um nome é "entrar em um processo de vida" (Ingold 2011:175). De outro, esses processos vitais são manipulados como signos por meio de uma linguagem do sensível, derivada de uma observação sutil do mundo não humano.

Se, acima, ao analisar os mitos referentes aos seres que engendraram os materiais empregados nos adornos cerimoniais, a diferença entre esses materiais não parecia relevante - na medida em que eles poderiam ser compreendidos, em conjunto, como exúvias -, neste segundo momento, ao adentrar a tradição dos benzimentos, vemos que por trás de tais materiais condensam-se imagens, histórias, territorialidades e relações de domínio particulares e mais complexas que aquelas que entrevíramos inicialmente. A manipulação dessas imagens-processos vitais particulares constitui a condição para a criação de objetos potentes, posto que o conhecimento dos benzimentos é imprescindível para se alterarem as relações de domínio em que os seres nomeados estão inseridos. ${ }^{31}$

Uma vez que retirar algo da floresta, das roças ou dos igapós é extrair de uma relação de domínio-engendramento, mas também de um corpo inteiro - de uma palmeira, uma ave, por exemplo-uma parte discreta, recontextuali- 
zando esta "coisa" em uma "cadeia operatória" de produção (Leroi-Gourhan 1943, 1945; Lemmonier 1993), a estética da transmissão de conhecimentos corporais, entrevista na mitologia, relaciona-se à estética da produção contemporânea de artefatos tangíveis e intangíveis. Dito de outro modo: fazer objetos é repetir os procedimentos criativos dos heróis míticos nos corpos de outros seres. Mas é fazê-lo de forma controlada e menos potente, por meio do conhecimento xamânico aqui discutido. Se a produção demiúrgica é monstruosa e excessiva, a produção humana é controlada e discreta, uma vez que os benzimentos permitem aos índios, por exemplo, fazer adornos sem ter de vomitá-los, ou de incinerarem-se em meio a um roçado. Nesta diferença residem a articulação e a distinção entre o saber demiúrgico e o saber humano característico da estética da produção rionegrina.

\section{Artefatos verbais e artefatos materiais}

Existe uma lógica semelhante que orienta a produção de benzimentos - artefatos intangíveis, feitos de imagens complexas - e adornos - artefatos tangíveis feitos de materiais complexos. Tal lógica pode ser entrevista se analisarmos a estética da produção dos benzimentos empregados na cura de doenças, o nosso último movimento neste texto.

Segundo Buchillet (1992), pesquisadora que estudou essa especialidade entre os Desana, os benzimentos de cura e proteção seguem uma estrutura composta de três movimentos básicos. Em primeiro lugar, o benzedor produz uma lista de nomes dos agentes da doença a ser curada - um artefato-imagem complexo daquilo que atua como um agente patógeno sobre o paciente. Em segundo lugar, ele age sobre essa imagem complexa por meio da destotalização dos agentes maléficos - ele arranca, quebra, corta em pedaços, mastiga, lava e esfria tais agentes. Em terceiro lugar, ele protege e reconstitui as partes do corpo afetadas pela doença. Isto é feito também por meio de uma lista de nomes-complexos que compõe, desta vez, um artefato-imagem como um antídoto para a doença (:220-1). ${ }^{32}$

O primeiro ponto que nos interessa refere-se aos deslocamentos espaciais. As listas de nomes resultam de buscas em locais distantes - as casas de origem das coisas nomeadas. Tal busca equivale, na elaboração de uma imagem verbal e intangível, à coleta de matérias-primas na produção de artefatos tangíveis. Um dos principais processos de composição notados por Hill (1993), entre os Wakuenai-Baniwa, nos benzimentos Kalidzamai foi o processo de "searching for", wadzuhiakaw nakuna (:23). Esse processo é caracterizado justamente por percorrer rapidamente diversos domínios cósmicos. 
A segunda aproximação importante refere-se aos procedimentos de destotalização e recontextualização. Se os adornos são artefatos compostos por exúvias - repletos de élitros de besouro, bicos de tucano, cascos de caramujos, cascos de tatu, pelos de macaco, peles, penas e plumas - os benzimentos também o são. Tanto a lista de nomes que descrevem os agentes da doença quanto a lista de nomes que descrevem o antídoto para doença são feitas, como os enfeites cerimoniais, de uma composição de partes destotalizadas de corpos.

No caso da imagem verbal da doença,

as principais [...] partes corporais [dos animais] potencialmente danosas para os indivíduos incluem: pele, cabelo, parasitas de pele, membros (patas, asas, barbatanas, caudas), dentes, bicos, calor residual do corpo; líquidos como sangue, suor, urina, cheiros, reflexos da pele, gritos... (Buchillet 1992:221).

Em alguns casos essas exúvias intangíveis são idênticas aos materiais empregados nos artefatos, como os "pelos, membros, dentes, bicos" citados acima; em outros, elas assumem um caráter sensível - os "reflexos da pele" ou os "gritos" mencionados por Buchillet - que tornam o artefato intangível singular em relação ao seu símile tangível. Algo derivado da potencialidade poética da modalidade de produção oral de imagens artefatuais. Mas o que nos interessa aqui é notar que aquilo que se passa na produção de artefatos tangíveis - a seleção de uma parte destotalizada e a sua recontextualização - também se passa na produção dos benzimentos.

\section{Apontamentos finais}

Neste artigo, vimos que a agência dos enfeites cerimoniais relaciona-se aos processos de desmembramento e retotalização de imagens e materiais característicos da estética da produção dos povos do ARN. A comparação entre benzimentos e artefatos demonstra que a dupla realidade da matéria - a sua presença física, na frente do produtor, e a sua existência por meio de imagens verbais - pode ser alvo de uma manipulação. Se um benzedor quebra, queima, destrói artefatos intangíveis, como o agente de uma doença, entendemos como a destruição de um enfeite, feito de um material semelhante - como o pente mawida de Halene e Kolhipeemi presente na história com que abri este texto - também tem efeito no mundo, e como a sua destruição foi capaz de fazer frente ao próprio Kowai-Jurupari. 
Vimos também que a produção de adornos no ARN emerge de um diálogo constante com entidades não humanas, de forma similar ao que se passa em diversos campos da produção da vida entre outros povos amazônicos (ver Guss 1989; Vilaça 2002; Miller 2009 por exemplo). Desta forma, a elaboração dos adornos rituais pode ser descrita como uma "arte ciumenta", termo cunhado por Lévi-Strauss (1986) para tratar dos cuidados característicos da produção cerâmica ameríndia visando sintetizar, justamente, a relação entre técnicas, materiais e constrangimentos rituais encontrada nos diversos temas analisados neste trabalho.

Por fim, a presente análise, ao ampliar o espectro temporal e relacional das trajetórias dos adornos cerimoniais rionegrinos, acrescenta algo às suas "biografias culturais" e "vidas sociais" (Kopytoff 1986; Appadurai 1986). Como vimos, a posse de adornos cerimoniais resulta da capacidade de ordenar as energias monstruosas de seres não humanos, tornando-as pacíficas e benignas àqueles que as dominam. Processo semelhante ocorre entre os Waiwai (cf. Howard 1991:68). Contudo, dentre esta população Carib, são indivíduos e não clãs que exibem a sua capacidade ordenadora e produtiva por meio de enfeites corporais. A despeito dessa diferença, a posse de adornos resulta, tanto lá quanto aqui, de uma extensão do sujeito coletivo não só sobre outros grupos humanos, mas também sobre as forças não humanas que os cercam. Assim, a vida social dos adornos rionegrinos inclui forçosamente os conteúdos técnicos, os episódios míticos e os aspectos rituais analisados neste texto - elementos que apontam para fatos anteriores à própria existência dos artefatos ou, se quisermos, para uma pré-história de sua produção.

Recebido em 04 de julho de 2016

Aprovado em 03 de abril de 2017

Thiago Oliveira é pós-doutorando (CAPES/PNPD) do Programa de Pós-Graduação em Antropologia Social, do Museu Nacional, Universidade Federal do Rio de Janeiro, Rio de Janeiro/RJ, Brasil. E-mail: <thiago.lc.oliveira@gmail.com> 


\section{Notas}

* Nota de agradecimento: Versões anteriores deste texto foram discutidas em dois grupos de trabalho - o GT 09 da $29^{\circ}$ RBA Natal-RN/2014 e o GT 32 da $11^{\text {a }}$ RAM, Montevideo/2015 - e em um seminário do LARMe/PPGAS-MN/UFRJ. Agradeço aos participantes dos GTs e do seminário pelas criticas e sugestões feitas ao trabalho. Agradeço também aos pareceristas anônimos pela leitura atenta e pelas sugestões de reformulações que permitiram precisar diversos pontos de minha argumentação. A Luiz Costa agradeço pelos comentários durante o processo de revisão. Pela autorização para a produção e a reprodução das imagens aqui analisadas agradeço aos técnicos e curadores das instituições museológicas visitadas durante a pesquisa, especialmente José Carlos Levinho, Ione Couto e Maria José Sardella (MI/FUNAI); Francisca Figols, Regivaldo da Silva e Ader Gotardo (MAE/USP); Edmundo Pereira e Crenivaldo Veloso (MN/UFRJ); Cláudia Lopes e Suzana Primo (MPEG/MCTIC). Finalmente, agradeço aos Baniwa, em especial a Laureano Valência, Carlos Fontes, André Fontes, Nazária Montenegro, Orlando Fontes, Afonso Fontes e Ilda Cardoso.

1 O uso do etnômio Baniwa aqui inclui os Wakuenai, estudados por Hill (e.g 1993) na Venezuela e os Koripako, estudados por Journet (1995) na Colômbia, e Xavier (2013), no Brasil. Os Hohodeni são um dos clãs Baniwa, junto aos Walipere-Dakenai, Dzáwinai, dentre outros.

2 As fotografias foram realizadas, no ano de 2012, no Museu do Índio (MI)/ Funai, no Museu Paraense Emílio Goeldi (MPEG)/MCTI e no Museu Nacional (MN)/ UFRJ. No ano de 2015, registrei o acervo do Museu de Arqueologia e Etnologia (MAE)/USP.

3 Sobre especialização artesanal no ARN ver e.g. Galvão (1964) e Ribeiro (1995).

4 Os índios da região possuem pelo menos três nomes: um tradicional de seu clã (que recebem no ritual de nascimento), um apelido em língua indígena, e um nome em português, adquirido no contato com os não indígenas (Hugh-Jones 2002:50).

5 Embora Kowai seja, com frequência, somente um personagem na tradição oral baniwa, Laureano confirmou que "eram muitos Kowai". Não devemos nos espantar, contudo, com esta multiplicação. Afinal, este personagem representa na tradição baniwa aquele que é "tudo em um". "Nós todos somos Kowai", como Wright (2015:1) registrou de um pajé.

6 Projeto de repatriamento patrocinado pelo Iphan (Cf. Oliveira e Andrello 2007).

7 Sobre esta perspectiva sistêmica ver, e.g., Hugh-Jones (1996a, 2002, 2009) e Neves (2001).

8 Os povos do ARN, ao lado dos povos do Alto Xingu, alguns grupos das Guianas, Japurá e Solimões estão entre os grupos indígenas sul-americanos cuja elaboração de artefatos atinge níveis elevados de complexidade e abrangência. Ver Santos-Granero (2009), Hugh-Jones (2009) e Miller (2009) para uma explanação sobre o tema. Sobre a chamada amnesia genealógica, ver Taylor (1993:675) e Descola (2006:259). E para uma crítica a estes últimos, cf. Chaumeil (2007:274-75). 
9 Ver Oliveira (2015, cap. 1) para uma discussão sobre a perda dos adornos no contexto dos descimentos coloniais.

10 Sobre o valor dos ornamentos cf. Nimuendajú (Livro de tombo, MN, objeto 19596) e Koch-Grünberg $(2005: 308,358)$.

11 Os grupos da região possuem basicamente dois tipos de especialistas rituais: o pajé maliri e o benzedor ñapakaitta (termos em baniwa). Eles correspondem, respectivamente, aos xamãs "vertical" e "horizontal" de Hugh-Jones (1996:33).

12 As mulheres utilizam plumas no corpo somente no rito que segue à reclusão da menarca. Elas são enfeitadas com plumas brancas de gavião coladas, por meio de uma resina vegetal, em pequenos globos brancos dispostos em linhas que atravessam braços, troncos e pernas.

13 Listagem feita a partir da combinação de relatos de Koch-Grünberg (2005:298-99) sobre os Tuyuka; de Århem (1981:79) sobre os Makuna; de Castro (2012:149) sobre os Wanano; de Hugh-Jones (2014:162) sobre os Barasana, e de Saake (1976:286-291), junto aos meus dados de campo, sobre os Baniwa.

14 Neste sentido, os índios do ARN ocupam um polo oposto ao de grupos como os Kashinawa (ver Kensinger 1991), que não só evitam a simetria, como não transformam, em geral, os materiais que empregam em seus ornamentos, privilegiando o volume tridimensional ao invés do bidimensional.

15 Entre estes últimos os adornos são minia, nome que se refere às araras (Ara Macao), xerimbabo prototípico, e também às flautas Jurupari, consideradas, paradoxalmente, ancestrais e xerimbabos dos humanos atuais. Ver Maia (2009) sobre os "instrumentos-xerimbabos" Baré, e Martini (2012) para os "adornos-xerimbabo" Tariano.

16 Levantamento baseado em Van Velthem (1975) e em pesquisa de campo realizada em 2014, com auxílio do guia ornitológico de Shulenberg et. al (2007). Para facilitar a leitura, compilo aqui, na mesma ordem de apresentação, as designações lineanas dos pássaros mencionados, faço o mesmo, em seguida, para os mamíferos e répteis: Casmerodius albus; Sarcoramphus papa - Cathartidae; Ara macao; Ara chloroptera; Amazona sp; Ramphastus sp; Cairina moschata; Spizaetus ornatus; Mitu mitu, Crax sp, Crax alector; Gallus domesticus; Meleagris gallopavo; Eurypiga helias; Rupicola rupícola; Cotinga cotinga; Ostinops sp e Dacnis cayana.

17 Respectivamente: Pteronura brasiliensis; Puma concolor; Panthera onça; Lagothrix lagotricha; Alouatta caraya; Cebus apela; Cebus n. Nigrivittatu; Callicebus dubius; Tayassu pecari e Pecari tajacu; Sciuridae (família); Bradypus variegatus; T. Tetradactyla; Dasypodidae.

18 Respectivamente: Serrasalminae (sub família); Alligatoridae; Lachesis muta

19 Respectivamente: Ischnosiphon arouma; Socratea exorrhiza (Mart.); Bactris setosa; Astrocaryum aculeatum; Ananas erectifolius sativa; Hevea brasiliensis. 
20 Para análises exaustivas desta mitologia, ver Wright $(1998,2013)$ e Hill (1993).

21 Sobre a lança-chocalho, ou murucú-maracá, ver Murray (1986), Hugh-Jones (2009) e Oliveira (2015:175 ss).

22 A palavra-ikolika tem, para os Baniwa, diferentes referentes. Diz-se-ikoika para tudo o que é utilizado no corpo para o embelezamento. O termo também se refere aos adornos de uma forma geral.

23 O problema da distribuição da pessoa, como se sabe, remonta ao relacionalismo de Strathern (1988). Na melanésia, como explicou a autora, pessoas e coisas interagem carregando consigo os traços de relações precedentes que as constituíram (cf. Gell 1999 e Hugh-Jones 2001).

24 Da mesma maneira que os adornos, os instrumentos cerimoniais "sagrados", na região, são animais constituídos de um corpo vegetal.

25 E de outras regiões também. Cf. Van Velthem (2009) sobre os seres corporificados em objetos e os processos de "desambiguização" necessários para torná-los artefatos puros, entre os Wayana, grupo Carib do Oiapoque.

26 Cf. Buchillet (1992), Hill (1993), Wright (1993), Cayon (2010) e Lolli (2010) sobre benzimentos. Em inglês autores usam spells, chants ou incantations para se referir ao tema. Em francês, soufle. Tal tradição pode ser aproximada dos cantos Marubo (Cesarino 2010, 2013), e das rezas do alto Xingu (Carlos Fausto, comunicação pessoal).

27 Wright (1993) distingue entre benzimentos comuns (Napakaitta) e os benzimentos dos alimentos (Kalidzamai). Os últimos teriam um alcance mais amplo do que os primeiros, tanto em termos espaciais quanto no que se refere aos seres mencionados (:9-10).

28 Uso o termo "coisa" numa acepção mais ampla que abarca mais do que objetos e artefatos, mas também construtos imateriais e até seres vivos, como os seres humanos. Sobre esta acepção, ver Hodder (2011:42).

29 Quando se juntam em uma determinada estrofe (um conjunto de nomes) - o que é bastante comum - considero também que estes nomes são um verso deste conjunto.

30 Emprego o termo "mapa visual" a partir de Howard (1991:68), que analisa um caso semelhante entre os Waiwai.

31 O conhecimento dos benzimentos delimita certas esferas de circulação de materiais e de produção de objetos, sendo a mais exclusiva aquela correspondente às coisas produzidas pelos pajés-maliri e trocadas entre eles. Neste sentido, os nomes de benzimentos podem ser compreendidos como uma "licença" ou "patente" neste sistema regional.

32 Ver também Lolli $(2010,2014)$ para um exemplo Yuhupdeh de benzimento de cura de dor no braço. 
ANDRELLO, Geraldo. 2006. Cidade Do Índio: Transformações E Cotidiano Em Iauaretê. São Paulo: Editora UNESP; ISA; Rio de Janeiro: NUTI. APPADURAI, Arjun. 1986. The social life of things. Cambridge: Cambridge University Press.

ÅRHEM, Kaj. 1981. Makuna social organization. Uppsala: Academiae Ubsaliensis.

1988. Makuna: the portrait of an Amazonian people. Fotos Diego Samper. Washington: Smithsonian Institution Press.

BUCHILLET, Dominique. 1992. "Nobody is there to hear". In: J. Langdon \& G. Baer (eds.), Portals of power. Albuquerque, Novo México, USA: University of New Mexico Press. pp. 211-230.

CABALZAR, Aloísio. 2000. "Descendência e aliança no espaço Tuyuka". Revista de Antropologia, 43(1):61-88. . (org.). 2005. Peixe e gente no Alto Rio Tiquié. São Paulo: ISA/ São Gabriel: FOIRN.

CABALZAR, Flora. 2010. Até Manaus, até Bogotá. Os Tuyuka vestem seus nomes como ornamentos. Dissertação de Mestrado, Universidade de São Paulo.

CASTRO, Pedro Rocha. 2012. Antes os brancos não existiam. Tese de Doutorado, PPGAS/MN/UFRJ.

CAYÓN, Luís. 2008. Cayon, "Ide Ma: El camino de agua". Antípoda, 7: 141-73.

. 2010. Penso, logo crio. A teoria makuna do mundo. Tese de Doutorado, Universidade de Brasília.

CESARINO, Pedro. 2010. "Donos e duplos". Revista de Antropologia, 53(1): 147-97.

. 2013. "Cartografias do cosmos". Mana, 19(3): 437-71.
CHAUMEIL, Jean-Pierre. 2007. "Bones, flutes, and the dead". In: C. Fausto \& M. Heckenberger (eds.), Time and memory in indigenous Amazonia. Florida: University Press of Florida. pp. 243-283.

CORNELIO et al. 1999. Waferinaipe Ianheke. A sabedoria dos nossos antepassados. Coleção NIRN. São Gabriel da Cachoeira: FOIRN.

CORREDOR, Kenny. 2011. El Cacurí (Wahiro). Tecnología y significado. Dissertação de Mestrado, Universidade dos Andes, Bogotá.

DORTA, Sonia Ferraro. 1981. Paríko, etnografia de um artefato plumário. Vol. 4. São Paulo: FAPESMP/ Universidade de São Paulo.

DESCOLA, Phillipe. 2006. As lanças do crepúsculo. São Paulo: Cosac Naify.

FAUSTO, Carlos. 2007. "Feasting on People." Current Anthropology 48 (4): 497-530.

. 2008. "Donos demais...". Mana. Estudos de Antropologia Social, 14(2): 329-366. . 2011. "Le Masque de L'animiste...", Gradhiva 13: 48-67.

FERREIRA, Tatiana Amaral Sanches. 2014. Basá busá: riqueza, cultura e política no alto rio Negro. Dissertação, São Carlos: PPGAS - UFSCar.

GALVÃO, Eduardo E. 1964 [1959]. "Aculturação indígena no rio Negro". Boletim MPEG. Antropologia, nova série, Belém, 7:1-65.

1979. Encontro de sociedades. São Paulo: Paz e Terra.

GARNELO, Luiza (org.). 2005. Mitoteca baniwa. São Gabriel: FOIRN.

GELL, Alfred. 1998. Art and agency. Oxford: Clarendon Press. 
1999. "Strathernograms, or the Semiotics of Mixed Metaphors." In: Gell. The Art of Anthropology. London: Athlone Press: 29-75.

GOLDMAN, Irving. 1979. The Cubeo. Urbana: University of Illinois Press. GONZÁLEZ-ÑÁÑEZ, Omar. 2007. Las literaturas indígenas Maipure-arawakas. Caracas: Fundación Editorial El Perro y La Rana.

GUSS, David M. 1989. To weave and sing. Berkeley: University of California Press.

HILL, Jonathann. 1993. Keepers of sacred chants. Tucson: The University of Arizona Press.

HODDER, Ian. 2011. Entangled. Nova York: Wiley and Sons, Inc.

HOWARD, Catherine. 1991. "Fragments of the heavens". In: Reina \& Kesinger (eds.), The gift of birds. Philadelphia: University of Pennsylvania. pp. 5069.

HUGH-JONES, Christine. 1979. From the milk river. Cambridge: Cambridge University Press.

HUGH-JONES, Stephen. 1979. The Palm and the Pleiades. Cambridge: Cambridge University Press. . 1996a. "Shamans, prophets, priests and pastors". In N. Thomas \& C. Humphrey (eds.), Shamanism, history, and the state, Ann Arbor: University of Michigan Press. pp. 32-75. . 1996b. "Bonnes raisons ou mauvaise conscience? De l' ambivalence de certains Amazoniens envers la consommation de viande". Terrain, $\mathrm{n}^{\circ}$ 26. pp. 1-39.

. 2001. "The gender of some Amazonian gifts...." In Gregory \& Tuzin (org.) Gender in Amazonia and Melanesia. Berkley. Univ. of California Press: pp. 245-78.

. 2002. "Nomes Secretos e Riqueza Visível...", MANA. Estudos de Antropologia Social, 8(2): 45-68.
. 2009 "The Fabricated Body...". In: Santos-Granero (ed.) The Occult Life of Things. Arizona: University of Arizona Press: pp. 33-59.

.2014 "Caixa de Pandora: estilo altorionegrino." $R @ U, 6$ (1), jan./jun. 2014: 155-173.

INGOLD, Tim. 2011. Being alive. London/ New York: Routledge.

JOURNET, Nicholas. 1995. Les paix des jardins. Paris: Institut D'Ethnologie, Musée de L'Homme.

KENSINGER, Kenneth. 1991. "Feathers make us beautiful". In: R. E. Reina \& K. M. Kensinger (orgs.), The gift of birds. Philadelphia: University $\mathrm{Mu}-$ seum Publication. pp. 40-49.

KOCH-GRÜNBERG，Theodor. 2005 [1903-1904]. Dois anos entre os indígenas. Manaus: EDUA/ FSDB.

KOPYTOFF, Igor. 1986. "The cultural biography of things". In: A. Appadurai (org.), The social life of things. Cambridge: Cambridge University Press. pp. 64-91.

KUMU, Umúsin Panlõn \& KENHÍRI, Tolam Ãn. 1995 [1980]. Antes o mundo não existia. São Gabriel: FOIRN.

LEA, Vanessa. 2012. Riquezas intangíveis de pessoas partíveis. São Paulo: Edusp.

LEMONNIER, Pierre. 1993. Technological choices. Londres: Routledge.

LEROI-GOURHAN, A. 1943. L'homme et la matière. Paris: Albin Michel.

. 1945. Milieu et technique. Paris: Albin Michel.

LÉVI-STRAUSS, Claude. 1986. A oleira ciumenta. São Paulo: Brasiliense.

LOLLI, Pedro. 2010. As redes de trocas rituais dos Yuhupdeh no Igarapé Castanho. Tese de Doutorado, USP. . 2014. "Atravessando pessoas no noroeste Amazônico". Mana, 20(2):281-305. 
MAIA, Paulo. 2009. Desequilibrando o convencional: estética e ritual com os Baré do ARN (AM). Tese de Doutorado, PPGAS/MN/UFRJ.

MARTINI, André. 2012. "O retorno dos mortos". Revista de Antropologia, 55(1):331-355.

MILLER, Joana. 2009. "Things as Persons". In: Santos-Granero (ed.), The occult life of things. Tucson: University of Arizona Press. pp. 60-80.

MURRAY VINCENT, William. 1986. "Máscaras. Objetos rituais do ARN". In: B. Ribeiro (org.), Suma etnológica brasileira. Petrópolis: Vozes. pp. 150-71.

NEVES, E. G. 2001. "Indigenous historical trajectories in the upper Rio Negro Basin". In: Colin McEwan; Cristiana Barreto \& Eduardo Neves (eds.), Unknown Amazon. Londres: British Museum Pubns Ltd. pp. 266-286.

NIMUENDAJÚ, Curt. 1950. "Reconhecimento dos rios Içána, Ayarí e Uaupés". Journal de la Société des Américanistes, 39(1):125-182.

OLIVEIRA, Ana Gita \& ANDRELLO, Geraldo (orgs.). 2007. Dossiê IPHAN 7 - Cachoeira de Iauaretê. Brasília: IPHAN.

OLIVEIRA, Thiago Lopes da Costa. 2015. Os Baniwa, os Artefatos e a Cultura Material no alto rio Negro. Tese. Rio de Janeiro: PPGAS - MN / UFRJ.

OVERING, Joanna. 1989. "The æsthetics of production". Dialectical Anthropology, 14:159-75.

REICHEL-DOLMATOFF, Gerardo. 1971. Amazonian cosmos. Chicago: University of Chicago Press.

RAMOS, José Barreto et al. 2012. Pássaros-adornos dos filhos da cobra de pedra. São Gabriel: FOIRN/ São Paulo: ISA.
RIBEIRO, Berta G. 1988. Dicionário do artesanato indígena. Belo Horizonte: Itatiaia/ São Paulo: Editora da USP. 1995. Os índios das águas pretas. São Paulo: Companhia das Letras/ Edusp.

SANTOS-GRANERO, Fernando (org.). 2009. The occult life of things. Arizona: The University of Arizona Press.

SAAKE, Wilhelm G. 1976. "Uma narração mítica entre os Baniwa". In: E. Schaden (org.), Leituras de etnologia brasileira. São Paulo: Companhia Editora Nacional. pp. 286-291.

SCHULENBERG, Thomas S. et al. 2007. Birds of Peru. Princeton: Princeton University Press.

STRATHERN, Marilyn. 1988. The Gender of the Gift. Berkeley: Univ. of California Press.

TAYLOR, A-C. 1993. "Remembering to forget". Man, New Series, 28(4):653678.

TURNER, Terence S. 1980. "The social skin". In: J. Cherfas \& R. Lewin (eds.), Not work alone. London: Temple Smit. pp. 112-140.

WRIGHT, Robin M. 1993. "Pursuing the spirit". Amerindia, 18:1-40.

. 1998. Cosmos, self and history in baniwa religion. Austin, Texas: University of Texas Press.

. 1999. "Apresentação e notas". In: Cornelio et al (ed.), Waferinaipe Ianheke. Coleção NIRN. São Gabriel: FOIRN. pp. 9-29. 2013. Mysteries of the jaguar shamans... Lincoln: University of Nebraska Press.

. 2015. "Musical Body of the Universe". Tipití, 13(1):1-22.

UMÚSIN PANLÕN KUMU (Firmiano Arantes Lana); TOLAMÃN KENHÍRI (Luiz Gomes Lana). 1980. Antes o mundo não existia. São Gabriel: UNIRT/FOIRN. 
VAN VELTHEM, Lucia Hussak. 1975. "Plumária tukano". Boletim MPEG, Nova Série, pp. 1-39. 1998. A pele de Tuluperê. Belém: MPEG.

2003. O belo é a fera. Lisboa: Assírio e Alvim/MNE.
VILAÇA, Aparecida. 2002. "Making kin out of others in Amazonia". JRAI, 8(2): 347-65.

XAVIER, Carlos. 2013. Os Koripako do alto Içana: etnografia de um grupo indígena evangélico. Tese de Doutorado, PPGAS/MN/UFRJ. 
CORPOS PARTIDOS: ADORNOS

CERIMONIAIS, BENZIMENTOS

RITUAIS E A ESTÉTICA DA

PRODUÇÃO NO ALTO RIO NEGRO
PARTIBLE BODIES: CEREMONIAL ORNAMENTS, SPELLS AND THE AESTHETICS OF PRODUCTION IN THE UPPER RIO NEGRO

\section{Resumo}

Este artigo aborda os envolvimentos entre os índios do alto rio Negro e os seus adornos cerimoniais a partir de uma etnografia realizada entre os Baniwa do clã Hohodeni, um coletivo de língua Arawak que vive na região. Após discutir a morfologia destes objetos, destaco a diferença entre a sua produção nos tempos originários e nos tempos atuais. Esta análise indicará como o conhecimento mítico e ritual é mobilizado para a transformação de seres vivos em artefatos, situando as relações entre humanos, animais e vegetais no conjunto mais amplo de relações entretidas entre humanos e não humanos. Ao final, comparo os adornos aos benzimentos rituais necessários para fabricá-los, sugerindo uma visão mais ampla da "estética da produção" rionegrina.

Palavras-chave: adornos corporais, benzimentos rituais, estética da produção, Baniwa, alto rio Negro.

\begin{abstract}
This article discusses how the Amerindians of the Upper Rio Negro engage with their ceremonial ornaments through an ethnography of the Baniwa of the Hohodeni clan, an Arawak speaking people. After discussing the morphology of these objects, I highlight the difference between their production in the past and the present. This analysis will show how mythic and ritual knowledge is mobilized in the transformation of living beings into artefacts, placing human, animal, and plant interactions within the broader set of relations between humans and nonhumans. Finally, I compare the ornaments to the ritual spells that are needed to fabricate them, proposing a broader view of the Upper Rio Negro "aesthetics of production".
\end{abstract}

Keywords: bodily ornaments, ritual spells, aesthetics of production, Baniwa, Upper Rio Negro. 
CUERPOS PARTIDOS: ADORNOS CEREM ONIALES, BENDICIONES RITUALES Y LA ESTÉTICA DE LA PRODUCCIÓN EN EL ALTO RÍO NEGRO

\section{Resumen}

Este artículo aborda los vínculos entre los indios del alto río Negro y sus adornos ceremoniales a partir de una etnografía realizada entre los Baniwa del clan Hohodeni, un colectivo de lengua Arawak que habita en la región. Después de discutir la morfología de estos objetos, resaltaré la diferencia entre su producción en los tiempos originarios y en los tiempos actuales.
Este análisis delineará la manera en que el conocimiento mítico y ritual es movilizado para la transformación de seres vivos en artefactos, situando las interacciones entre humanos, animales y vegetales en el conjunto más amplio de relaciones entre los seres humanos y no humanos. Finalmente, comparo los adornos a los rezos rituales necesarios para fabricarlos, sugiriendo una visión más amplia de la "estética de la producción" rionegrina.

Palabras clave: adornos corporales, rezos rituales, estética de la producción, Baniwa, alto río Negro. 